\title{
Source apportionment of carbonaceous aerosols in Beijing with radiocarbon and organic tracers: insight into the differences between urban and rural sites
}

\author{
Siqi Hou ${ }^{1, \star}$, Di Liu ${ }^{1, a} \star$, Jingsha $X u^{1}$, Tuan V. Vu ${ }^{1, b}$, Xuefang $W^{2}{ }^{2}$, Deepchandra Srivastava ${ }^{1}$, Pingqing Fu ${ }^{3}$, \\ Linjie Li ${ }^{4, c}$, Yele Sun ${ }^{4}$, Athanasia Vlachou ${ }^{5}$, Vaios Moschos ${ }^{5}$, Gary Salazar ${ }^{6}$, Sönke Szidat ${ }^{6}$, André S. H. Prévôt ${ }^{5}$, \\ Roy M. Harrison ${ }^{1, d}$, and Zongbo Shi ${ }^{1}$ \\ ${ }^{1}$ School of Geography Earth and Environmental Science, University of Birmingham, Birmingham, B15 2TT, UK \\ ${ }^{2}$ School of Earth Sciences and Resources, China University of Geosciences, Xueyuan Road 29, Beijing, 100083, China \\ ${ }^{3}$ Institute of Surface-Earth System Science, Tianjin University, Tianjin, 300072, China \\ ${ }^{4}$ State Key Laboratory of Atmospheric Boundary Layer Physics and Atmospheric Chemistry Institute of Atmospheric, \\ Physics, Chinese Academy of Sciences, Beijing, 100029, China \\ ${ }^{5}$ Laboratory of Atmospheric Chemistry, Paul Scherrer Institute, Villigen PSI, 5232, Switzerland \\ ${ }^{6}$ Department of Chemistry and Biochemistry \& Oeschger Centre for Climate Change Research, \\ University of Bern, Bern, 3012, Switzerland \\ ${ }^{a}$ now at: Institute of Atmospheric Physics, Chinese Academy of Sciences, Beijing, 100029, China \\ ${ }^{b}$ now at: School of Public Health, Imperial College London, London, UK \\ ${ }^{c}$ now at: Department of Chemistry and Molecular Biology, University of Gothenburg, Gothenburg 41296, Sweden \\ dalso at: Department of Environmental Sciences/Centre of Excellence in Environmental Studies, \\ King Abdulaziz University, P.O. Box 80203, Jeddah, 21589, Saudi Arabia \\ ฟThese authors contributed equally to this work.
}

Correspondence: Roy M. Harrison (r.m.harrison@bham.ac.uk) and Zongbo Shi (z.shi@bham.ac.uk)

Received: 30 September 2020 - Discussion started: 19 November 2020

Revised: 1 April 2021 - Accepted: 7 April 2021 - Published: 28 May 2021

\begin{abstract}
Carbonaceous aerosol is a dominant component of fine particles in Beijing. However, it is challenging to apportion its sources. Here, we applied a newly developed method which combined radiocarbon $\left({ }^{14} \mathrm{C}\right)$ with organic tracers to apportion the sources of fine carbonaceous particles at an urban (IAP) and a rural (PG) site of Beijing. $\mathrm{PM}_{2.5}$ filter samples $(24 \mathrm{~h})$ were collected at both sites from 10 November to 11 December 2016 and from 22 May to 24 June 2017. ${ }^{14} \mathrm{C}$ was determined in 25 aerosol samples (13 at IAP and 12 at PG) representing low pollution to haze conditions. Biomass burning tracers (levoglucosan, mannosan, and galactosan) in the samples were also determined using gas chromatography-mass spectrometry (GC-MS). Higher contributions of fossil-derived $\mathrm{OC}\left(\mathrm{OC}_{\mathrm{f}}\right)$ were found at the urban site. The $\mathrm{OC}_{\mathrm{f}} / \mathrm{OC}$ ratio decreased in the summer samples (IAP: $67.8 \pm 4.0 \%$ in winter and $54.2 \pm 11.7 \%$ in summer;
\end{abstract}

PG: $59.3 \pm 5.7 \%$ in winter and $50.0 \pm 9.0 \%$ in summer) due to less consumption of coal in the warm season. A novel extended Gelencsér (EG) method incorporating the ${ }^{14} \mathrm{C}$ and organic tracer data was developed to estimate the fossil and non-fossil sources of primary and secondary OC (POC and SOC). It showed that fossil-derived POC was the largest contributor to $\mathrm{OC}(35.8 \pm 10.5 \%$ and $34.1 \pm 8.7 \%$ in wintertime for IAP and PG, $28.9 \pm 7.4 \%$ and $29.1 \pm 9.4 \%$ in summer), regardless of season. SOC contributed $50.0 \pm 12.3 \%$ and $47.2 \pm 15.5 \%$ at IAP and $42.0 \pm 11.7 \%$ and $43.0 \pm 13.4 \%$ at PG in the winter and summer sampling periods, respectively, within which the fossil-derived SOC was predominant and contributed more in winter. The non-fossil fractions of SOC increased in summer due to a larger biogenic component. Concentrations of biomass burning $\mathrm{OC}\left(\mathrm{OC}_{\mathrm{bb}}\right)$ are resolved by the extended Gelencsér method, with average contribu- 
tions (to total OC) of $10.6 \pm 1.7 \%$ and $10.4 \pm 1.5 \%$ in winter at IAP and PG and $6.5 \pm 5.2 \%$ and $17.9 \pm 3.5 \%$ in summer, respectively. Correlations of water-insoluble OC (WINSOC) and water-soluble OC (WSOC) with POC and SOC showed that although WINSOC was the major contributor to POC, a non-negligible fraction of WINSOC was found in SOC for both fossil and non-fossil sources, especially during winter. In summer, a greater proportion of WSOC from non-fossil sources was found in SOC. Comparisons of the source apportionment results with those obtained from a chemical mass balance model were generally good, except for the cooking aerosol.

\section{Introduction}

Carbonaceous aerosols, often one of the most abundant components $(20 \%-80 \%)$ in atmospheric aerosol particles, have a crucial impact on the global climate, air quality, and human health (He et al., 2001; Huang et al., 2014; Jimenez et al., 2009; Song et al., 2007; Zhou et al., 2018). The total content of carbonaceous aerosols (i.e., total carbon, TC) can be divided into organic carbon (OC) and elemental carbon (EC) according to their physical, chemical, and optical properties. The source of EC is from incomplete combustion of fossil fuel or biomass, while OC mainly originates from primary emissions from sources such as coal combustion, traffic emissions, cooking, and biomass burning, as well as from gas-particle conversion (Yang et al., 2016). It is very challenging to quantify the contributions from different sources to $\mathrm{OC}$ and EC because of the limited information on the sources, atmospheric loading, and composition of organic aerosols (Huang et al., 2014). Radiocarbon $\left({ }^{14} \mathrm{C}\right)$ analysis is a powerful tool for the quantification of fossil and non-fossil contributions to carbonaceous aerosols, as non-fossil sources contain a high contemporary ${ }^{14} \mathrm{C}$ content, while the fossil fractions are free of ${ }^{14} \mathrm{C}$ (Zotter et al., 2014; Bernardoni et al., 2013; Liu et al., 2013; Szidat et al., 2004, 2006, 2009). A previous study in north-east China found a dominant fossilfuel contribution to EC $(76 \pm 11 \%)$ and found that non-fossil sources are major contributors to OC $(66 \pm 11 \%)$ (Zhang et al., 2016). Non-fossil sources of OC were major contributors to the fine particle pollution in Beijing during the APEC summit (Liu et al., 2016a). Moreover, clear seasonal trends of non-fossil and fossil source contributions to waterinsoluble OC (WINSOC) and water-soluble OC (WSOC) were found. Non-fossil sources were the major contributor (59\%) to WINSOC in summer and autumn, whereas fossil fuel emissions were predominant in winter and spring (Liu et al., 2013). Proportions of non-fossil sources in TC and WSOC associated with biogenic emissions increased during spring and summer, with maxima (85\% and $117 \%$, respectively) in May (Pavuluri et al., 2013). However, ${ }^{14} \mathrm{C}$ measurements do not permit direct discrimination of specific sources (e.g. biomass burning or secondary OC, SOC) of modern carbon. A combination with other techniques gives further insight into the characteristics of SOC (Minguillon et al., 2011; Szidat et al., 2006, 2009; Yttri et al., 2011). For example, applying Latin hypercube sampling with different OC/EC ratios, relative contributions of primary and secondary organic carbon were estimated (Zhang et al., 2016). ${ }^{14} \mathrm{C}$ analysis combined with AMS-PMF (positive matrix factorization analysis of data from an online Aerodyne aerosol mass spectrometer) data has contributed to the identification of sources from primary emissions and secondary formation (Barrett et al., 2015; Zhang et al., 2018, 2017; Vlachou et al., 2018).

The Gelencsér method provides a first-order source apportionment of organic aerosol from fossil fuel combustion, biomass burning, biogenic emissions, and secondary organic aerosol, using measurements of specific organic tracers emitted by fossil and non-fossil sources and their OC/EC ratios derived from literature (Gelencsér et al., 2007). This method was derived in a European context, but for China the inclusion of food cooking and coal combustion is required. Based upon this consideration, an extended Gelencsér (EG) method that includes quantification of fossil and contemporary EC and $\mathrm{OC}$ by ${ }^{14} \mathrm{C}$ analysis has been developed in this study. The diversity of fuel types and combustion conditions makes the selection of OC/EC ratios for biomass burning difficult due to large uncertainties. For non-fossil sources of SOC, quantification by the method of Gelencsér et al. (2007) is totally dependent on the source apportionment of OC from biomass burning, and thus a cautious selection of ratios has been adopted in this study.

Biomass burning is an important source of both EC and OC, which can affect large areas of the world through long-range transport (Andreae and Merlet, 2001). It is also a key component when applying source apportionment by the Gelencsér method. As levoglucosan (1,6-anhydro- $\beta$-Dglucopyranose, LG) is an almost specific biomass burning tracer as the main pyrolysis product from cellulose (Puxbaum et al., 2007; Simoneit et al., 1999), concentrations of OC from biomass burning can be obtained by multiplying LG with suitable OC/LG ratios (Gelencsér et al., 2007; Zdrahal et al., 2002). However, the wide range of OC/LG ratios associated with changes in the biofuel types and combustion conditions cause great uncertainty in the estimation (Cheng et al., 2013; Fu et al., 2012; Gelencsér et al., 2007). To mitigate these differences from types of material and the burning conditions, a typical ratio of 12.2-12.5 (12.3 on average) was documented in Andreae and Merlet (2001) by considering the biofuels of savanna and crop residues. This ratio is widely accepted in many studies (Andreae and Merlet, 2001; Fu et al., 2012; T. Zhang et al., 2008; Zhang et al., 2007) and has been used to estimate the contributions of biomass burning in Beijing, which ranged from $8 \%$ to $50 \%$ (Cheng et al., 2013; Kang et al., 2018; Liu et al., 2017; T. Zhang et al., 2008; Zhang et al., 2017). However, a single ratio is not representative of all local conditions, and more specific 
methods are needed. ${ }^{14} \mathrm{C}$ analysis can provide accurate concentrations of EC from biomass burning, assuming that EC from non-fossil sources is exclusively from biomass burning. Introducing $\mathrm{EC}_{\mathrm{nf}}$ concentrations from ${ }^{14} \mathrm{C}$ analysis into the Gelencsér method of using OC/LG ratios provides valuable extra information and allows the method to be extended to include other sources.

Beijing, capital of China, has experienced severe $\mathrm{PM}_{2.5}$ pollution for decades. This has been the subject of extensive research. However, few studies have sought to differentiate the fossil and non-fossil sources of SOC, even though they provide key information on the precursor and formation mechanisms of SOC. In this study, measurements of $\mathrm{PM}_{2.5}$, $\mathrm{OC}$, and EC, along with biomass burning tracers, were conducted simultaneously at urban and rural sites of Beijing in the winter of 2016 and summer of $2017 .{ }^{14} \mathrm{C}$ measurements of EC, OC, WINSOC, and WSOC were carried out subsequently on filter samples to enable source apportionment of fossil vs. non-fossil sources. A novel extended Gelencsér method combining ${ }^{14} \mathrm{C}$ analysis has been developed to explore the source apportionment of OC and EC, with SOC from fossil and non-fossil sources being quantified. The source apportionment results were compared with those by chemical mass balance (CMB). Correlations of WINSOC and WSOC with different sources of OC were also performed to study the formation mechanisms of SOC.

\section{Methodology}

\subsection{Aerosol sampling}

Daily $\mathrm{PM}_{2.5}$ (particles with aerodynamic diameter less than $2.5 \mu \mathrm{m})$ samples were collected at an urban site $\left(39.98^{\circ} \mathrm{N}\right.$, $116.39^{\circ} \mathrm{E}$; Institute of Atmospheric Physics, IAP) and a rural site $\left(40.17^{\circ} \mathrm{N}, 117.05^{\circ} \mathrm{E}\right.$, Pinggu, $\left.\mathrm{PG}\right)$ in Beijing during a winter campaign (10 November-11 December 2016) and a summer campaign (22 May-24 June 2017) as part of the Atmospheric Pollution and Human Health in a Chinese megacity (APHH China) programme; further information on the sampling sites is available in Shi et al. (2019). The urban site is a typical urban background site but may be subject to multiple local influences such as cooking emissions from nearby restaurants. The rural site is located in Pinggu District, close to a village surrounded by farmland. It is $\sim 60 \mathrm{~km}$ north-east of urban Beijing at the junction of Beijing, Tianjin, and Hebei provinces. A two-lane road is about $200-300 \mathrm{~m}$ north of the sampling site, but its traffic volume is relatively low.

High-volume air samplers (Tisch, USA) with a flow rate of $1.1 \mathrm{~m}^{3} \mathrm{~min}^{-1}$ were collected on pre-combusted $\left(450{ }^{\circ} \mathrm{C}\right.$, $6 \mathrm{~h})$ quartz filters (Pallflex, 8 in $\times 10$ in). Field blanks were collected by placing filters onto the filter holder for a few minutes without pumping before and after the campaign. After sampling, each exposed or blank filter was wrapped individually with aluminium foil and stored at $-20^{\circ} \mathrm{C}$ in the dark prior to analysis. Details of the sample collection are described elsewhere (Shi et al., 2019).

\subsection{Chemical analysis}

\subsubsection{OC, EC, and major inorganic ions}

$\mathrm{OC}$ and EC mass concentrations were determined with the DRI2015 carbon analyser with the EUSAAR_2 (European Supersites for Atmospheric Aerosol Research) transmittance protocol. Replicate analyses were conducted once every 10 samples. Blank samples (corresponding to 0.40 and $0.01 \mathrm{\mu g} \mathrm{m}^{-3}$ for OC and EC) were analysed to correct the sample results. The limits of detection of OC and EC were estimated to be 0.03 and $0.05 \mu \mathrm{g} \mathrm{m}^{-3}$. Details of the OC/EC measurement method are described elsewhere (Paraskevopoulou et al., 2014). Major ions including $\mathrm{SO}_{4}^{2-}$, $\mathrm{NO}_{3}^{-}, \mathrm{NH}_{4}^{+}, \mathrm{Na}^{+}, \mathrm{K}^{+}$, and $\mathrm{Cl}^{-}$were determined on water extracts using an ion chromatograph (Dionex, Sunnyvale, CA, USA), with detection limits less than $0.01 \mu \mathrm{g} \mathrm{m}^{-3}$. The uncertainties for OC and EC were less than $10 \%$ and less than $5 \%$ for inorganic ions (Xu et al., 2020).

\subsubsection{Biomass burning tracers}

The methodology to determine biomass burning tracers, including levoglucosan, mannosan, and galactosan, is described elsewhere (Fu et al., 2016). Recoveries for target compounds were better than $80 \%$ as obtained by spiking standards to pre-combusted quartz filters followed by extraction and derivatization. Field blank filters were analysed using the procedure used for the samples above, but no target compounds were detected. Duplicate analyses showed analytical errors of less than $15 \%$.

\subsection{Radiocarbon $\left({ }^{14} \mathrm{C}\right)$ analysis}

The ${ }^{14} \mathrm{C}$ in total carbon (TC), water-insoluble TC (WINSTC), and EC was determined on 25 (13 from IAP and 12 from $\mathrm{PG}$ ) time-integrated high-volume $\mathrm{PM}_{2.5}$ quartz fibre (QF) filter samples. Samples collected during both haze and non-haze days were selected in winter to better understand the pollution sources. $\mathrm{PM}_{2.5}$ concentrations on 22 November and 1 December at IAP and PG sites were lower than $75 \mathrm{\mu g} \mathrm{m}^{-3}$ and regarded as non-haze air days, in contrast to other wintertime samples collected during haze pollution days. During the summer, typical samples were selected, with $\mathrm{PM}_{2.5}$ concentrations of $42.5 \pm 26.5$ and $42.7 \pm 21.2 \mu \mathrm{g} \mathrm{m}^{-3}$ at IAP and PG, respectively. The concentrations of $\mathrm{PM}_{2.5}, \mathrm{EC}$, and $\mathrm{OC}$ and the corresponding nonfossil fractions of these selected days are shown in Table 2.

The method of ${ }^{14} \mathrm{C}$ measurement of carbonaceous aerosols has been described elsewhere (Agrios et al., 2015; Levin et al., 2010; Szidat et al., 2014; Vlachou et al., 2018; Zhang et al., 2012, 2016; Zotter et al., 2014). The ${ }^{14} \mathrm{C}$ of TC and WINSTC was measured using a one-step protocol under pure 
$\mathrm{O}_{2}(99.9995 \%)$ at $760^{\circ} \mathrm{C}$ for $400 \mathrm{~s}$ (Vlachou et al., 2018) using an elemental analyser coupled with the accelerator mass spectrometer Mini Carbon Dating System (MICADAS) at the Laboratory for the Analysis of Radiocarbon (LARA; University of Bern) (Zhang et al., 2012; Szidat et al., 2014). The EC fraction was separated by an OC/EC analyser (Model 4L, Sunset Laboratory, USA) with the use of the Swiss_4S protocol (Zhang et al., 2012), which was coupled online with the MICADAS (Agrios et al., 2015). Each filter sample was extracted with water before the measurements to minimize the charring effect during the separation of EC from the WINSOC.

${ }^{14} \mathrm{C}$ results were expressed as fractions of modern $\left(f_{\mathrm{M}}\right)$, i.e., the fraction of the ${ }^{14} \mathrm{C} /{ }^{12} \mathrm{C}$ ratio of the sample related to that of the reference year 1950. The data analysis was carried out accounting for the blank correction (one field blank per site was analysed, not relevant for EC), decay of ${ }^{14} \mathrm{C}$ since the 1950s, nuclear bomb correction, charring of WINSOC ( $\sim 1 \%$ ), and EC yield after OC removal (IAP: $62 \pm 6 \%$; PG: $76 \pm 8 \%$ ) (Zhang et al., 2012, 2016; Zotter et al., 2014).

Non-fossil fractions $\left(f_{\mathrm{NF}}\right)$ were determined from their corresponding $f_{\mathrm{M}}$ values and reference values for pure nonfossil sources by

$f_{\mathrm{NF}}=\frac{f_{\mathrm{M}}}{f_{\mathrm{NF}, \mathrm{ref}}}$.

Different values for the $f_{\mathrm{NF} \text {,ref }}$ were applied for the bomb peak correction (Levin, et al. 2010). For EC, the $f_{\mathrm{NF} \text {,ref }}$ is $1.10 \pm 0.05$ (Lewis et al., 2004; Palstra and Meijer, 2014), given that biomass burning is assumed to be the only nonfossil source of EC. For OC, it is calculated as

$f_{\mathrm{NF}, \mathrm{ref}}=p_{\mathrm{bio}} \cdot f_{\mathrm{M}, \mathrm{bio}}+p_{\mathrm{bb}} \cdot f_{\mathrm{M}, \mathrm{bb}}$

where $f_{\mathrm{M}, \mathrm{bb}}$ and $f_{\mathrm{M} \text {,bio }}$ are from biomass burning and biogenic sources, respectively, which are $1.10 \pm 0.05$ and $1.023 \pm 0.015$ (Lewis et al., 2004; Zotter et al., 2014), while $p_{\text {bio }}$ and $p_{\mathrm{bb}}$ are the proportions of biogenic source and biomass burning, respectively, which are 0.1 and 0.9 in winter and 0.5 and 0.5 in summer (Levin et al., 2010).

Analogously, the non-fossil fractions of OC, WSOC, and WINSOC ( $f_{\mathrm{NF}, \mathrm{OC}}, f_{\mathrm{NF}, \mathrm{WSOC}}$, and $\left.f_{\mathrm{NF}, \mathrm{WINSOC}}\right)$ were calculated by following a mass-balance-like approach:

$$
\begin{aligned}
& \mathrm{OC}_{\mathrm{nf}}=\mathrm{OC} \cdot f_{\mathrm{NF}, \mathrm{OC}}=\mathrm{TC} \cdot f_{\mathrm{NF}, \mathrm{TC}}-\mathrm{EC} \cdot f_{\mathrm{NF}, \mathrm{EC}} \\
& \begin{aligned}
\mathrm{WSOC}_{\mathrm{nf}}= & \mathrm{WSOC} \cdot f_{\mathrm{NF}, \mathrm{WSOC}} \approx \mathrm{WSOC} \cdot f_{\mathrm{NF}, \mathrm{WSTC}} \\
= & \mathrm{TC} \cdot f_{\mathrm{NF}, \mathrm{TC}}-\mathrm{WINSTC} \cdot f_{\mathrm{NF}, \mathrm{WINSTC}} \\
\mathrm{WINSOC}_{\mathrm{nf}} & =\mathrm{WINSOC} \cdot f_{\mathrm{NF}, \mathrm{WINSOC}} \\
& =\mathrm{OC} \cdot f_{\mathrm{NF}, \mathrm{OC}}-\mathrm{WSOC} \cdot f_{\mathrm{NF}, \mathrm{WSOC}},
\end{aligned}
\end{aligned}
$$

where TC and EC are the concentrations of total and elemental carbon, respectively, and $f_{\mathrm{NF}, \mathrm{TC}}, f_{\mathrm{NF}, \mathrm{EC}}$, and $f_{\mathrm{NF}, \mathrm{WINSTC}}$

\begin{tabular}{|c|c|}
\hline & Extended Gelencsér method \\
\hline $\mathrm{EC}_{\mathrm{bb}}$ & $\approx \mathrm{EC}_{\mathrm{nf}}$, measured by ${ }^{14} \mathrm{C}$ \\
\hline $\mathrm{EC}_{\mathrm{f}}$ & measured by ${ }^{14} \mathrm{C}$ \\
\hline $\mathrm{OC}_{\mathrm{nf}}$ & measured by ${ }^{14} \mathrm{C}$ \\
\hline $\mathrm{OC}_{\mathrm{f}}$ & measured by ${ }^{14} \mathrm{C}$ \\
\hline $\mathrm{POC}_{\mathrm{f}}$ & $\mathrm{EC}_{\mathrm{f}} \cdot(\mathrm{OC} / \mathrm{EC})_{\mathrm{f}, \min }$ \\
\hline $\mathrm{SOC}_{\mathrm{f}}$ & $\mathrm{OC}_{\mathrm{f}}-\mathrm{POC}_{\mathrm{f}}$ \\
\hline $\mathrm{POC}_{\mathrm{nf}}$ & $\mathrm{EC}_{\mathrm{nf}} \cdot(\mathrm{OC} / \mathrm{EC})_{\mathrm{nf}, \min }$ \\
\hline $\mathrm{SOC}_{\mathrm{nf}}$ & $\mathrm{OC}_{\mathrm{nf}}-\mathrm{POC}_{\mathrm{nf}}$ \\
\hline $\mathrm{OC}_{\mathrm{bb}}$ & $\mathrm{EC}_{\mathrm{nf}} \cdot(\mathrm{OC} / \mathrm{EC})_{\mathrm{bb}}=\mathrm{LG} \cdot(\mathrm{OC} / \mathrm{LG})_{\mathrm{bb}}$ \\
\hline $\mathrm{OC}_{\text {bio }}$ & ignored \\
\hline $\mathrm{OC}_{\mathrm{ck}}$ & $\mathrm{POC}_{\mathrm{nf}}-\mathrm{OC}_{\mathrm{bb}}$ \\
\hline
\end{tabular}
are the non-fossil fractions of TC, EC, and WINSTC, respectively. The fraction of fossil-fuel sources was calculated by
Table 1. Equations for ${ }^{14} \mathrm{C}$-based source apportionment; see Sect. 3.2 for details.

$f_{\mathrm{FF}}=1-f_{\mathrm{NF}}$. The uncertainties were determined by error propagation. The mass concentration errors were assumed to be $10 \%$ for EC and $6 \%$ for OC and TC (typical values for EUSAAR2) (Zhang et al., 2016).

\subsection{Extended Gelencsér method including ${ }^{14} \mathrm{C}$ data}

An extended Gelencsér method including ${ }^{14} \mathrm{C}$ data was developed to quantify the fossil and non-fossil sources of primary and secondary OC (POC and SOC) along with OC from biomass burning and cooking $\left(\mathrm{OC}_{\mathrm{bb}}\right.$ and $\left.\mathrm{OC}_{\mathrm{ck}}\right)$. The equations for the extended Gelencsér method are listed in Table 1. The detailed selection of the $\mathrm{OC} / \mathrm{EC}$ ratios will be discussed in Sect. 3.2.

\subsection{Chemical mass balance (CMB) model and AMS/ACSM-PMF analysis}

Results on the same sets of samples from a chemical mass balance (US EPA CMB8.2) model and AMS/ACSM-PMF analysis (positive matrix factorization analysis of data from an online Aerodyne aerosol mass spectrometer at IAP and Aerosol Chemical Speciation Monitor at PG) were compared with ${ }^{14} \mathrm{C}$-based source apportionment. Details on the experimental details and data analyses can be found in $\mathrm{Xu}$ et al. (2021) and Wu et al. (2020). The CMB utilizes a linear least-squares solution considering both uncertainties in source profiles and ambient measurements to ensure reliable fitting results. In order to better represent the source characteristics, the source profiles applied in this model were mostly from local studies in China (Cai et al., 2017; Wang et al., 2009; Y. X. Zhang et al., 2008; Zhang et al., 2007; Zhao et al., 2015), except vegetative detritus (Rogge et al., 1993; Wang et al., 2009). Details of the selection of the organic marker species can be found in Yin et al. (2010, 2015).

Experimental details on the AMS and ACSM-PMF method can be found elsewhere (Ng et al., 2011; Sun et al., 2016; Xu et al., 2019). The ACSM data were analysed 
for the mass concentrations and size distributions of nonrefractory submicron aerosol $\left(\mathrm{NR}-\mathrm{PM}_{1}\right)$ species using the high-resolution data analysis software package PIKA (Sun et al., 2020). Positive matrix factorization was performed on high-resolution mass spectra of $\mathrm{V}$ mode and $\mathrm{W}$ mode to retrieve potential organic aerosol (OA) factors from different sources (Paatero and Tapper, 1994; Ulbrich et al., 2009). The organic matter/organic carbon (OM/OC) factor used for cooking OA (COA) is 1.38 (Xu et al., 2019).

\section{Results and discussion}

\subsection{Overall results}

\subsubsection{Characteristics of $\mathrm{PM}_{2.5}, \mathrm{OC}$ and EC concentrations}

Mass concentrations of $\mathrm{PM}_{2.5}, \mathrm{OC}, \mathrm{EC}$, and biomass burning tracers are shown in Fig. 1 and are summarized in Table 2, along with the meteorological conditions during the observation campaign in IAP and PG. The average concentrations of $\mathrm{PM}_{2.5}$ were $91.2 \pm 63.7$ and $99.7 \pm 77.8 \mu \mathrm{g} \mathrm{m}^{-3}$ at the IAP and PG sites, respectively, in winter, and $30.2 \pm 14.8$ and $27.5 \pm 12.9 \mu \mathrm{g} \mathrm{m}^{-3}$ at the IAP and PG sites in summer. The highest $24 \mathrm{~h}$ concentration in winter is $239.9 \mu \mathrm{g} \mathrm{m}^{-3}$ (IAP) and $294.3 \mu \mathrm{g} \mathrm{m}^{-3}$ (PG), and more than $53 \%$ and $46 \%$ of the days have daily $\mathrm{PM}_{2.5}$ concentrations higher than the Chinese air quality standard $\left(\mathrm{PM}_{2.5}\right.$ concentrations exceeding $75 \mu \mathrm{g} \mathrm{m}^{-3}$ are defined as haze conditions) in IAP and PG during the observation period. In summer, the air quality was improved, with $\mathrm{PM}_{2.5}$ concentrations ranging from 12.2 to 78.8 and 11.6 to $70.3 \mu \mathrm{g} \mathrm{m}^{-3}$ in IAP and PG, respectively.

Organic carbon and elemental carbon (OC and EC) are important constituents of $\mathrm{PM}_{2.5}$, accounting for $30.9 \pm 9.3 \%$ and $43.6 \pm 17.9 \%$ of $\mathrm{PM}_{2.5}$ mass at the IAP and PG sites in winter and $26.8 \pm 9.2 \%$ and $37.3 \pm 12.6 \%$ in summer. The concentrations of EC showed a strong correlation with $\mathrm{OC}$ at both sites during the winter and summer (Table S1 in the Supplement). The average EC concentrations for ${ }^{14} \mathrm{C}$ analysis varied from $3.8 \pm 2.1 \mu \mathrm{g} \mathrm{m}^{-3}$ (IAP) and $5.4 \pm 2.6 \mu \mathrm{g} \mathrm{m}^{-3}$ (PG) in winter and $1.1 \pm 0.3 \mu \mathrm{g} \mathrm{m}^{-3}$ (IAP) and $2.0 \pm 0.7 \mu \mathrm{g} \mathrm{m}^{-3}$ (PG) in summer for the urban and rural sites, respectively. The mass concentration of $\mathrm{OC}$ for ${ }^{14} \mathrm{C}$ analysis was $4.1-44.9$ and $12.1-85.0 \mu \mathrm{g} \mathrm{m}^{-3}$ at IAP and PG

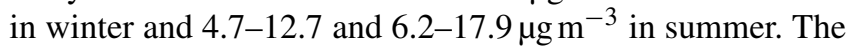
selected samples are well representative as their concentrations were very close to those from the whole campaign. The average $\mathrm{OC}$ concentration for ${ }^{14} \mathrm{C}$ in winter was 3.2 and 4.3 times higher than in summer at IAP and $\mathrm{PG}$, respectively. The OC/EC ratios at IAP and PG were in the range of 4.114.9 and 6.2-14.6 in winter and 4.6-14.8 and 4.4-28.3 in summer, which were all higher than 2.0 or 1.1 (Chow et al., 1996; Castro et al., 1999), suggesting an important contribution from secondary organic carbon (SOC).

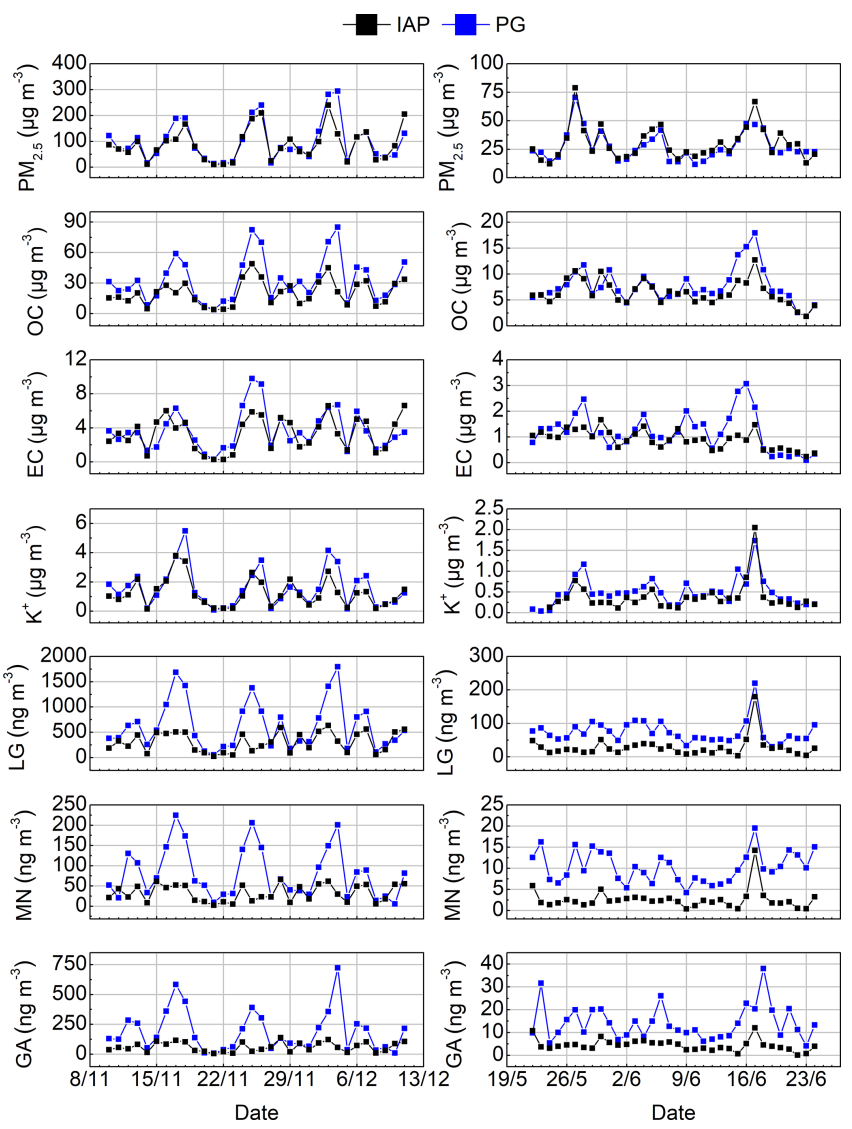

Figure 1. Time series of $\mathrm{PM}_{2.5}$ and its major components at IAP and PG during winter (left) and summer (right).

\subsubsection{Fossil and non-fossil sources of EC and $\mathrm{OC}$ based on radiocarbon $\left({ }^{14} \mathrm{C}\right)$ analysis}

Figure 2 shows the absolute concentrations of fossil and nonfossil fractions of OC and EC and the relative contributions. $\mathrm{EC}_{\mathrm{f}}$ refers to $\mathrm{EC}$ from coal combustion and liquid fossil fuel (i.e., mainly vehicle emissions) and $\mathrm{EC}_{\mathrm{nf}}$ from biomass burning (Gray and Cass, 1998). As shown in Fig. 2, high concentrations of $\mathrm{EC}_{\mathrm{f}}$ and $\mathrm{EC}_{\mathrm{nf}}$ were found in both urban and rural sites in winter, suggesting elevated emissions from primary fossil and non-fossil sources like coal combustion and biomass burning. Residential coal consumption and biomass burning are still important in winter, especially in rural areas, due to intensive heating activities in the cold season. $\mathrm{EC}_{\mathrm{f}}$ contributed $7.6 \pm 2.1 \%$ and $6.0 \pm 1.4 \%$ to TC at the IAP and PG sites in winter and $6.9 \pm 1.6 \%$ and $8.9 \pm 2.6 \%$ in summer. Most of the fossil fractions of EC are within the range of previous studies in urban Beijing (67\%-96\% of EC) (Liu et al., 2020, 2017; Zhang et al., 2016, 2017). Higher contributions of $\mathrm{EC}_{\mathrm{f}}$ were found on the polluted days in wintertime (Table 2), showing that the $\mathrm{PM}_{2.5}$ concentrations may be elevated due to direct emission from coal combustion and vehicle exhaust. Fractions of $\mathrm{EC}_{\mathrm{nf}}$ increased slightly in summer 


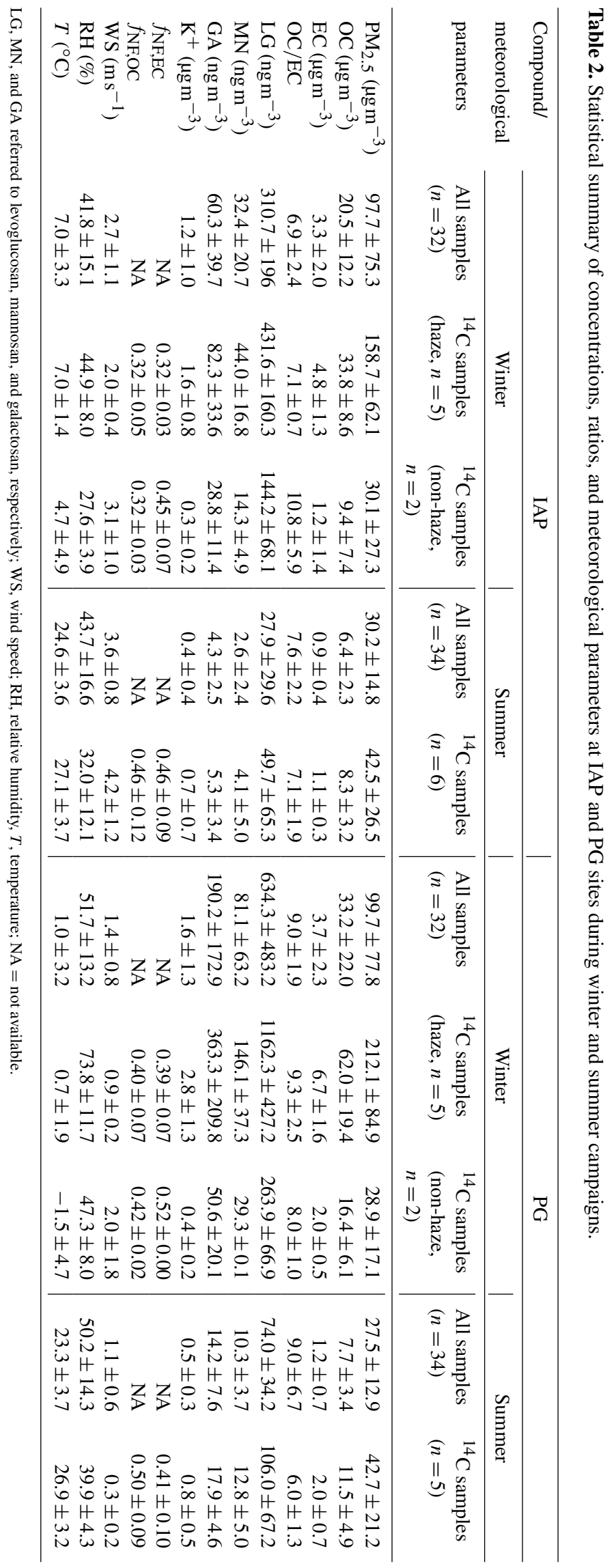


due to the regional open burning activities during the postharvest period of wheat, which is common in North China (Li et al., 2016; Yan et al., 2006).

$\mathrm{OC}$ from fossil sources $\left(\mathrm{OC}_{\mathrm{f}}\right)$ arises mainly from coal combustion and vehicle emissions, while $\mathrm{OC}$ from non-fossil sources $\left(\mathrm{OC}_{\mathrm{nf}}\right)$ comes mainly from biomass burning, biogenic emissions, and cooking. Although fossil sources are the main contributor to $\mathrm{OC}(67.8 \pm 4.0 \%$ and $59.3 \pm 5.7 \%$ at IAP and PG sites in winter, compared to $54.2 \pm 11.7 \%$ and $50.0 \pm 9.0 \%$ in summer), relative contributions of $\mathrm{OC}_{\mathrm{nf}}$ were significantly increased in summer. These results are similar to previous studies in urban Beijing, which found a contribution of $66 \pm 11 \%$ ranging from $45 \%$ to $82 \%$ in $\mathrm{PM}_{1}$ collected in 2013/14 (Zhang et al., 2015, 2017). The increased contribution of $\mathrm{OC}_{\mathrm{nf}}$ in summer is likely to due to the enhancement of biomass burning and biogenic emissions (both primary and through SOC), as well as the decline in emissions from fossil sources such as coal burning, considering that cooking OC emission is unlikely to change with season.

Fossil and non-fossil sources of WSOC and WINSOC were also quantified by the ${ }^{14} \mathrm{C}$ measurement. Among the four fractions, WINSOC $\mathrm{f}_{\mathrm{f}}$ had the highest contribution to TC in winter $(37.9 \pm 4.5 \%$ at IAP and $36.2 \pm 4.7 \%$ at PG), followed by $\mathrm{WSOC}_{\mathrm{f}}(22.1 \pm 5.2 \%)$ at IAP and $\mathrm{WINSOC}_{\mathrm{nf}}$ $(20.8 \pm 3.4 \%)$ at PG. In summer, the fraction of WINSOC $_{\mathrm{f}}$ fell to $24.4 \pm 9.3 \%$ at IAP and $21.8 \pm 4.6 \%$ at PG, accompanied by increased fossil and non-fossil contributions from WSOC fractions. The increase of $\mathrm{WSOC}_{\mathrm{f}}$ fractions in summer implied an enhanced contribution from oxidized volatile organic compounds (VOCs) and aged primary fossil-derived $\mathrm{OC}$, and $\mathrm{WSOC}_{\mathrm{nf}}$ is probably associated with biomass burning and secondary OC. Moreover, WINSOC was dominated by fossil sources at both sites in winter (IAP: $72.6 \pm 3.6 \%$; PG: $63.4 \pm 6.5 \%$ ), while the non-fossil fractions significantly increased from winter to summer. Similarly, WSOC was mainly fossil-derived in winter, while it tends to be accumulated in non-fossil fractions in summer (fossil fraction in WSOC, IAP: $60.5 \pm 6.6 \%$ in winter, $50.8 \pm 12.3 \%$ in summer; PG: $51.6 \pm 8.7 \%$ in winter, $47.7 \pm 17.4 \%$ in summer). The contribution of $\mathrm{OC}_{\mathrm{nf}}$ to $\mathrm{OC}$ increased with both nonfossil fractions in WINSOC and WSOC increasing. Even though WINSOC $_{\mathrm{nf}}$ and $\mathrm{WSOC}_{\mathrm{nf}}$ cannot be attributed specifically to biomass burning, biogenic emissions, cooking, or secondary formation, it is likely that biogenic-derived POC and SOC make a pronounced contribution. Details of contributions of each fraction to primary and secondary OC will be discussed in Sect. 3.2.

\subsection{Source apportionment by an extended Gelencsér method}

Gelencsér et al. (2007) reported a method for the source apportionment of carbonaceous aerosol into fractions from biomass burning, road traffic, and secondary organic aerosol, applicable to Europe where these are the dominant sources.
In order to use the same methodological concepts in China, the method required extending to include two further sources: coal combustion and cooking. To do so, the ${ }^{14} \mathrm{C}$ data were utilized.

\subsubsection{Biomass burning}

Levoglucosan (LG) is a typical biomass burning tracer, as the main pyrolysis product from cellulose. Much higher concentrations of LG were observed in the winter $\left(311 \pm 193 \mathrm{ng} \mathrm{m}^{-3}\right.$ at IAP and $634 \pm 483 \mathrm{ng} \mathrm{m}^{-3}$ at PG) than those in the summer $\left(27.9 \pm 29.6 \mathrm{ng} \mathrm{m}^{-3}\right.$ at IAP and $74.0 \pm 34.2 \mathrm{ng} \mathrm{m}^{-3}$ at PG). In addition, LG concentrations at the rural site were higher than those at the urban site in both winter and summer. This pattern is consistent with previous measurements in Table 3 (Chen et al., 2018; Kang et al., 2018; Li et al., 2018; Liu et al., 2016b; Salma et al., 2017; Sullivan et al., 2019; Yan et al., 2019; Zhu et al., 2017). The Pearson correlations of LG with $\mathrm{PM}_{2.5}, \mathrm{OC}$, and EC at IAP and PG are shown in Table S1. During winter, LG correlated well with $\mathrm{PM}_{2.5}, \mathrm{OC}$, and $\mathrm{EC}$ at $\mathrm{PG}$, with correlation coefficients of $0.89,0.89$, and 0.81 , respectively. These are higher than those at IAP (correlation coefficients of 0.56, 0.60, and 0.74 , respectively), suggesting a more significant influence of biomass burning upon $\mathrm{PM}_{2.5}$ in PG. The correlation coefficients in summer were much lower than those in winter for both sites, evidencing a reduced contribution of biomass burning activities to $\mathrm{PM}_{2.5}$. During the wintertime, the increasing use of biofuel for heating exacerbates the biomass pollution, and the stable atmospheric conditions also enhance the accumulation of LG (Shi et al., 2019). Compared with widely used cleaner fossil energy (i.e., natural gas, electricity, and liquefied petroleum gas) and renewable energy (i.e., solar energy) available in urban areas, rural households are still largely using straw and wood for cooking and heating (Hou et al., 2017). Moreover, open burning of crop residues during the post-harvest months (May to July and October to November in North China) in rural areas is still frequently performed in spite of prohibition by the government (Chen et al., 2017; $\mathrm{Li}$ et al., 2016). The water-soluble potassium ion $\left(\mathrm{K}^{+}\right)$has been used as a biomass burning tracer previously, due to its good relationship with LG. However, in this study, the Pearson correlation coefficients of $\mathrm{K}^{+}$with $\mathrm{LG}$ are 0.51 and 0.86 in winter and 0.85 and 0.51 in summer for IAP and PG (Table S1), indicating other non-biomass sources of $\mathrm{K}^{+}$. Indeed, the sources of $\mathrm{K}^{+}$in the atmosphere are diverse, including sea salt, cooking, dust, coal combustion, and waste incineration, which makes $\mathrm{K}^{+}$less suitable as a biomass burning tracer (Zhang, et al., 2010).

According to Gelencsér et al. (2007), EC from biomass burning $\left(\mathrm{EC}_{\mathrm{bb}}\right)$ can be derived by multiplying the LG concentrations first by $(\mathrm{OC} / \mathrm{LG})_{\mathrm{bb}}$ to give $\mathrm{OC}_{\mathrm{bb}}$ and then by $(\mathrm{EC} / \mathrm{OC})_{\mathrm{bb}}$. However, the $(\mathrm{OC} / \mathrm{LG})_{\mathrm{bb}}$ ratio is highly variable depending on the type of material and the conditions of burning, and the ratios can vary by orders of magnitude. 


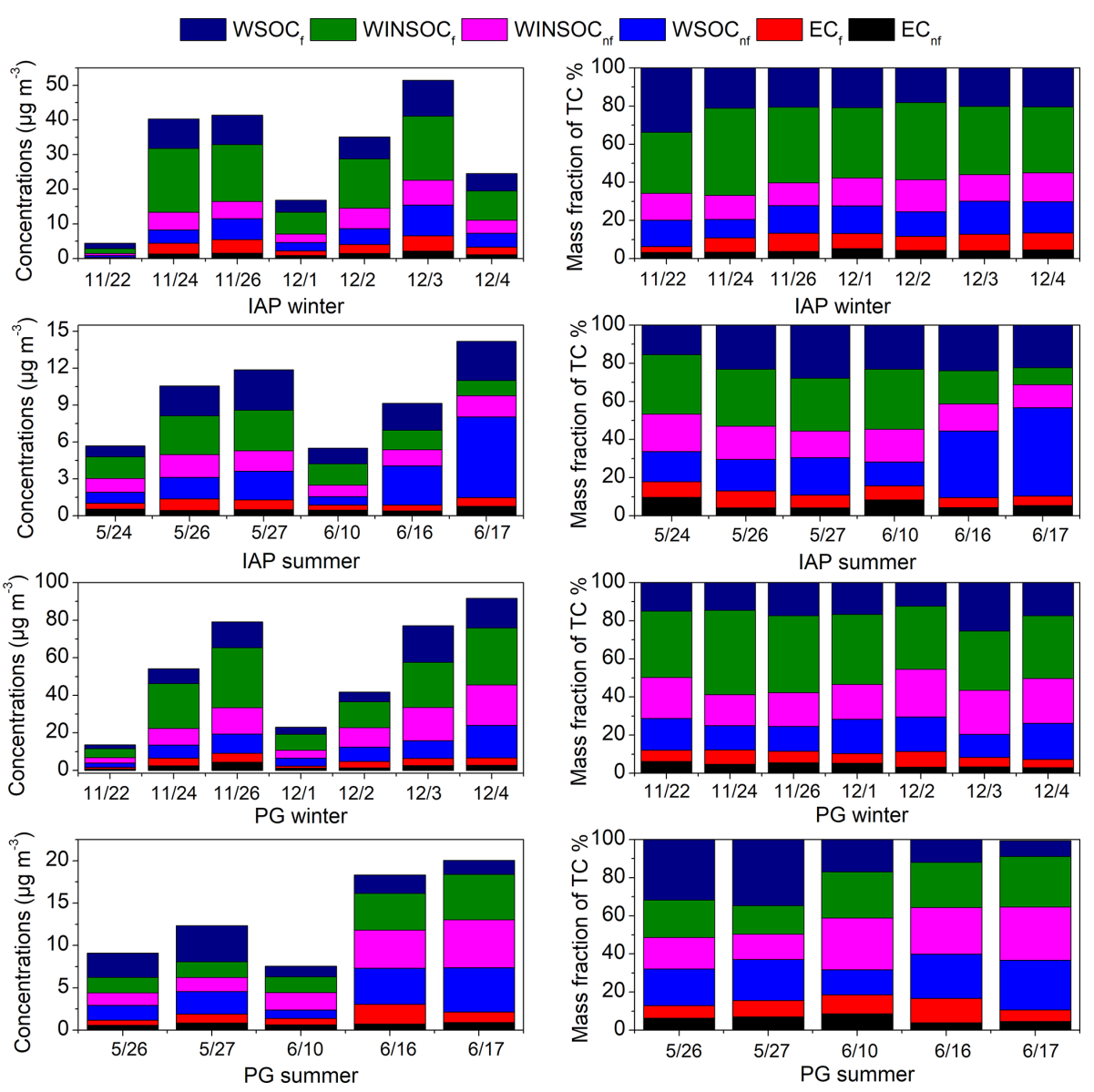

Figure 2. Time series of concentrations of $\mathrm{WSOC}_{\mathrm{f}}, \mathrm{WSOC}_{\mathrm{nf}}$, WINSOC $\mathrm{f}, \mathrm{WINSOC}_{\mathrm{nf}}, \mathrm{EC}_{\mathrm{f}}$, and $\mathrm{EC}_{\mathrm{nf}}$ (left) and their relative contributions to TC (right) during winter in 2016 and summer in 2017 at IAP and PG.

Table 3. Comparison of LG concentrations and OC from biomass burning in this study and related literature.

\begin{tabular}{|c|c|c|c|c|c|c|}
\hline Site & $\begin{array}{l}\text { Site } \\
\text { type }\end{array}$ & Sampling time & $\mathrm{LG} \mathrm{ng} \mathrm{m}^{-3}$ & $\mathrm{OC}_{\mathrm{bb}}$ contribution & $\begin{array}{l}\text { OC/LG used } \\
\text { for estimation }\end{array}$ & Reference \\
\hline Beijing & Urban & Winter (16 Nov-12 Dec 2016) & $310.7 \pm 196.0$ & $10.6 \pm 1.7 \%$ & & This study \\
\hline Beijing & Urban & Winter in $2013 / 14$ & $189,36.1-491$ & $12.2 \%, 3.61 \%-19.5 \%$ & 12.29 & Kang et al. (2018) \\
\hline Beijing & Urban & Winter in $2012 / 13$ & $361,171-730$ & $16.6 \%, 6.06 \%-35.2 \%$ & $12.20-12.50$ & Li et al. (2018) \\
\hline Wuhan & Urban & Winter (9 Jan-6 Feb 2013) & $950 \pm 421$ & $21 \% \pm 9 \%$ & $7.76 \pm 1.47$ & Liu et al. (2016b) \\
\hline Beijing & Urban & Summer (22 May-22 Jun 2017) & $27.9 \pm 29.6$ & $6.5 \pm 5.2 \%$ & & This study \\
\hline Beijing & Urban & Summer (9 Jun-8 Jul 2014) & $56.37 \pm 55.48$ & $14.8 \pm 9.4 \%$ & 20.83 & Yan et al. (2019) \\
\hline Beijing & Urban & Summer in 2014 & $12.4,0.84-26.8$ & $2.73 \%, 0.28 \%-5.60 \%$ & 12.29 & Kang et al. (2018) \\
\hline Beijing & Urban & Summer in 2012 & $61.8,13.9-317$ & $8.39 \%, 2.64 \%-12.5 \%$ & $12.20-12.50$ & Li et al. (2018) \\
\hline Beijing & Rural & Winter (16 Nov-12 Dec 2016) & $634.3 \pm 483.2$ & $10.4 \pm 1.5 \%$ & & This study \\
\hline Xi' an & Rural & Winter (17-26 Jan 2014) & $930 \pm 320$ in $\mathrm{PM}_{0.133}$ & $24 \%, 19 \%-32 \%$ & 12.2 & Zhu et al. (2017) \\
\hline Beijing & Rural & Summer (22 May-22 Jun 2017) & $74.0 \pm 34.2$ & $17.9 \pm 3.5 \%$ & & This study \\
\hline Zhengzhou & Suburban & Summer, BB episode in 2-21 Jun 2015 & $460-1230$ & $47.20 \%$ & 13.51 & Chen et al. (2018) \\
\hline Zhengzhou & Suburban & Summer, non-BB in 2-21 Jun 2015 & $200-290$ & $13.90 \%$ & 11.9 & Chen et al. (2018) \\
\hline Hebei & Rural & Summer (9 Jun-8 Jul 2014) & $205.94 \pm 304.35$ & $31.3 \pm 18.8 \%$ & 20.83 & Yan et al. (2019) \\
\hline
\end{tabular}

Therefore, EC concentrations from non-fossil sources determined by radiocarbon analysis $\left(\mathrm{EC}_{\mathrm{nf}}\right)$, assumed to arise almost solely from biomass burning, were used as an estimate of $\mathrm{EC}_{\mathrm{bb}}$. Hence,

$\mathrm{EC}_{\mathrm{nf}} \approx \mathrm{EC}_{\mathrm{bb}}=\mathrm{LG} \cdot(\mathrm{OC} / \mathrm{LG})_{\mathrm{bb}} \cdot(\mathrm{EC} / \mathrm{OC})_{\mathrm{bb}}$.
The ratios of levoglucosan to mannosan (LG/MN) and to galactosan (LG/GA) can help us to infer the $(\mathrm{OC} / \mathrm{LG})_{\mathrm{bb}}$ and $(\mathrm{EC} / \mathrm{OC})_{\mathrm{bb}}$ ratios from certain types of biomass fuel (Kawamura et al., 2012). Figure 3 shows the source pro- 


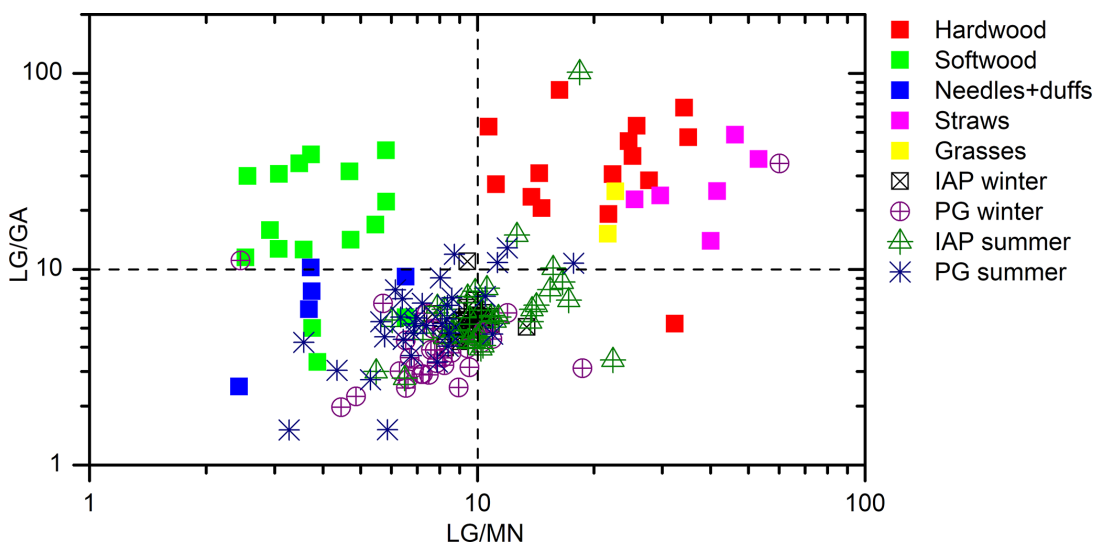

Figure 3. Scatter plot of LG/MN vs. LG/GA from different types of biomass burning emissions (Cheng et al., 2013; Sun et al., 2019a, b; LG, MN, and GA refer to levoglucosan, mannosan, and galactosan, respectively), including those measured in $\mathrm{PM}_{2.5}$ samples at IAP and PG during winter and summer. The range of $\mathrm{LG} / \mathrm{MN}$ is $7.66-13.41$ and 5.48-22.40 for IAP in winter and summer and 2.45-60.20 and 3.27-17.71 for PG in winter and summer, while the range of LG/GA is 3.98-6.92, 2.78-101.43, 1.97-34.66, and 1.51-13.39, respectively.

file for $\mathrm{LG} / \mathrm{MN}$ and $\mathrm{LG} / \mathrm{GA}$ ratios measured in emissions from controlled biomass burning experiments in previous studies (Cheng et al., 2013; Sun et al., 2019a,b). There is a clear boundary of $\mathrm{LG} / \mathrm{MN}$ ratios $(\sim 10)$ between softwood and hardwood burning (Kawamura et al., 2012). Using LG/GA ratios can help to identify the burning of straws, woods, needles, and grasses, where most of the LG/GA ratios from burning of hardwood, straws, and grasses are higher than 10, quite different from those of needle plants. LG/MN and LG/GA ratios cannot be used to separate the burning of straws from hardwood, but the burning of hardwood can be neglected considering the local forest types around Beijing (Cheng et al., 2013).

The measured LG/MN and LG/GA ratios in this study (Fig. 3) implied that the use of biofuels was mainly a mixture of softwood and crop straws. Compared with ratios in summer, $\mathrm{LG} / \mathrm{MN}$ and $\mathrm{LG} / \mathrm{GA}$ ratios in winter have a narrower range at both IAP and PG sites, and most of them converge at values lower than 10 , suggesting wood burning may be dominant in winter, and the contribution of straw burning increases in summer. It has been reported that firewood burning emissions in Beijing represent $47 \%-90 \%$ of the total biomass burning and could contribute more than $80 \%$ in winter (Zhou et al., 2017). Although the LG/MN and LG/GA ratios of maize burning and wheat burning are similar and cannot be used to distinguish the two, research into the yield of main crops and farming practices showed that the main straw burning in Beijing and nearby provinces may be associated with maize straw in October to November and wheat straw in May to July (Zhang et al., 2019).

These results suggest that softwood burning and straw burning are the main sources of aerosols from biomass burning in Beijing. Thus, EC from softwood burning and straw burning can be calculated as follows:

$$
\begin{aligned}
\mathrm{EC}_{\mathrm{nf}} & \approx \mathrm{EC}_{\mathrm{bb}}=\mathrm{EC}_{\mathrm{wood}}+\mathrm{EC}_{\text {straw }} \\
& =\mathrm{LG} \cdot f_{\text {wood }} \cdot(\mathrm{OC} / \mathrm{LG})_{\text {wood }} \cdot(\mathrm{EC} / \mathrm{OC})_{\text {wood }} \\
& +\mathrm{LG} \cdot f_{\text {straw }} \cdot(\mathrm{OC} / \mathrm{LG})_{\text {straw }} \cdot(\mathrm{EC} / \mathrm{OC})_{\text {straw }},
\end{aligned}
$$

where $f_{\text {wood }}$ represents the fraction of LG from softwood burning, and $f_{\text {straw }}$ represents the fraction of $\mathrm{LG}$ from straw burning. $f_{\text {straw }}=1-f_{\text {wood }}$, neglecting other sources of biomass burning. $f_{\text {wood }}$ can be expressed as

$$
f_{\mathrm{wood}}=\frac{\mathrm{EC}_{\mathrm{nf}}-\mathrm{LG} \cdot(\mathrm{OC} / \mathrm{LG})_{\mathrm{straw}} \cdot(\mathrm{EC} / \mathrm{OC})_{\mathrm{straw}}}{\left(\begin{array}{c}
(\mathrm{OC} / \mathrm{LG})_{\mathrm{wood}} \cdot(\mathrm{EC} / \mathrm{OC})_{\mathrm{wood}} \\
-(\mathrm{OC} / \mathrm{LG})_{\mathrm{straw}} \cdot(\mathrm{EC} / \mathrm{OC})_{\mathrm{straw}}
\end{array}\right) \cdot \mathrm{LG}} .
$$

As $f_{\text {wood }}$ should be in the range of $0-1$, it can be used as the limits of selected EC/OC and OC/LG ratios from softwood and straw. Details of the ratio selection can be found in the Supplement. Once values of $f_{\text {wood }}$ are confirmed, OC from softwood $\left(\mathrm{OC}_{\mathrm{wood}}\right)$ and straw burning $\left(\mathrm{OC}_{\text {straw }}\right)$ can be obtained by

$$
\begin{aligned}
& \mathrm{OC}_{\mathrm{wood}}=\mathrm{LG} \cdot f_{\mathrm{wood}} \cdot(\mathrm{OC} / \mathrm{LG})_{\text {wood }} \\
& \mathrm{OC}_{\text {straw }}=\mathrm{LG} \cdot\left(1-f_{\text {wood }}\right) \cdot(\mathrm{OC} / \mathrm{LG})_{\text {straw }} \\
& \mathrm{OC}_{\mathrm{bb}}=\mathrm{OC}_{\mathrm{wood}}+\mathrm{OC}_{\text {straw }} .
\end{aligned}
$$

The mass concentrations of $\mathrm{OC}_{\mathrm{bb}}$ and the contributions of $\mathrm{OC}_{\mathrm{wood}}$ and $\mathrm{OC}_{\text {straw }}$ are shown in Fig. 4. The average concentration of $\mathrm{OC}_{\mathrm{bb}}$ in IAP winter was $2.7 \pm 1.3 \mu \mathrm{g} \mathrm{m}^{-3}$, with a contribution of $10.6 \pm 1.7 \%$ to total $\mathrm{OC}$, which is about half that in PG winter $\left(4.8 \pm 2.4 \mu \mathrm{g} \mathrm{m}^{-3}, 10.4 \pm 1.5 \%\right)$. The $\mathrm{OC}_{\mathrm{bb}}$ concentrations fell in summer $\left(0.6 \pm 0.7 \mu \mathrm{g} \mathrm{m}^{-3}\right.$ at IAP, $2.0 \pm 0.8 \mu \mathrm{g} \mathrm{m}^{-3}$ at $\mathrm{PG}$ ); the contributions are $6.5 \pm 5.2 \%$ and $17.9 \pm 3.5 \%$, respectively. The rural site always has a higher $\mathrm{OC}_{\mathrm{bb}}$, which is consistent with our previous discussions. $\mathrm{OC}_{\mathrm{wood}}$ normally dominated $\mathrm{OC}_{\mathrm{bb}}$, while 

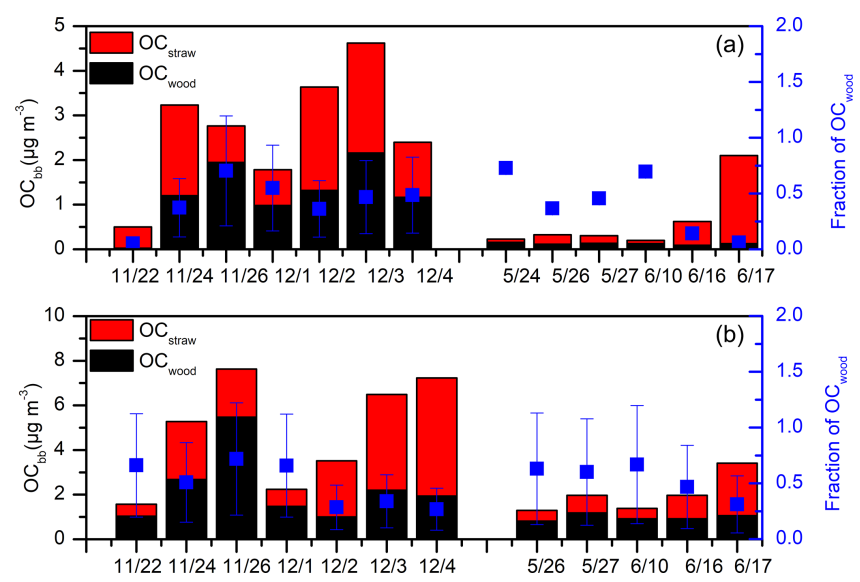

Figure 4. Concentrations of $\mathrm{OC}$ from softwood $\left(\mathrm{OC}_{\mathrm{wood}}\right)$ and $\mathrm{OC}$ from straw $\left(\mathrm{OC}_{\text {straw }}\right)$ at IAP (a) and PG (b) and variations of $\mathrm{OC}_{\text {wood }}$ fractions.

the increase of the $\mathrm{OC}_{\text {straw }}$ fraction may be attributed to the local open burning activities. The contributions of $\mathrm{OC}_{\mathrm{bb}}$ in this study are slightly different from previous studies (Table 3), with lower percentage contributions in the winter sampling period. However, if applying a value of 12.2, a typical OC/LG ratio widely used in previous studies (Andreae and Merlet, 2001; Fu et al., 2012; T. Zhang et al., 2008; Zhang et al., 2007), contributions of $\mathrm{OC}_{\mathrm{bb}}$ to $\mathrm{OC}$ would be $17.7 \%$ and $26.3 \%$ for IAP and PG in winter and $6.1 \%$ and $10.8 \%$ in summer, respectively. Compared with the results in this study, the ratio 12.2 may significantly overestimate the contributions of biomass burning in winter and underestimate the contributions in summer.

In addition, coal combustion may also emit LG, accounting for about $7 \%$ of LG in Beijing (Yan et al., 2018; Y. X. Zhang et al., 2008). Considering that the reported LG/MN and LG/GA ratios of coal combustion (both are in the range of 5-10) are close to those in our measurements, there may be a contribution from coal burning to levoglucosan, but if this amounts to $7 \%$ of levoglucosan, the percentage contribution of biomass burning to OC in winter falls to $10.3 \pm 1.6 \%$ and $10.2 \pm 1.5 \%$ at IAP and PG, respectively.

Besides the local emissions, regional transport of air masses can elevate the local OC and EC concentrations. To study the influence of regional transport on biomass burning particles, back trajectories and fire spots are plotted in Figs. S1 and S2 in the Supplement. As shown in Fig. S1, air masses at IAP and PG in winter originated from Hebei, Shanxi, and Inner Mongolia, and the fire spots showed low intensity of open burning activities along the air mass transport path during the measurement period. It suggests a less important effect of open burning through regional transport. During the summer, the open burning activities were greatly increased due to the harvesting of wheat (Zhang et al., 2019), which is confirmed by the fire spot distribution in Fig. S2.
Air masses from Hebei, Liaoning, and Shandong provinces, which contain particles from wheat straw burning, may have enhanced the concentrations of OC and EC in Beijing. Considering the open burning of straw is linked with a sudden increase of LG in the ambient atmosphere, the high LG concentrations accompanied with low fire spot intensity suggests a strong local emission, while days with high fire spot intensities may also be affected by regional transport. Combining the analysis of fire spots intensity and the $\mathrm{OC}_{\mathrm{wood}}$ fractions can help to identify the influence of local emissions and regional transport. Details of regional transport and sources of biomass burning are summarized in Table S2 in the Supplement.

\subsubsection{Other sources of $\mathrm{OC}$ and consistency with $\mathrm{CMB}$ and AMS/ACSM-PMF model results}

More detailed source apportionment of OC can be achieved by combining ${ }^{14} \mathrm{C}$ analysis with primary $\mathrm{OC} / \mathrm{EC}$ ratios for each source. $\mathrm{POC}_{\mathrm{f}}$ can be determined from $\mathrm{EC}_{\mathrm{f}}$ with primary fossil-fuel OC/EC emission ratios $(\mathrm{POC} / \mathrm{EC})_{\mathrm{f}}$. However, the $(\mathrm{POC} / \mathrm{EC})_{\mathrm{f}}$ ratios in previous studies $(1.12-2.08$ in winter, $0.40-0.77$ in summer; Zhang et al., 2017) give much lower $\mathrm{POC}_{\mathrm{f}}$ values compared to CMB results (Fig. S5 in the Supplement), even though mostly good correlations were found. In reality, $(\mathrm{POC} / \mathrm{EC})_{\mathrm{f}}$ ratios vary greatly according to combustion conditions, fuel types and even measurement method for OC and EC (Chow et al., 2001; Han et al., 2016), and it is very hard to accurately predict the $(\mathrm{POC} / \mathrm{EC})_{\mathrm{f}}$ ratio for a given area. Hence, we used the lowest $(\mathrm{OC} / \mathrm{EC})_{\mathrm{f}}$ ratios $(\mathrm{OC} / \mathrm{EC})_{\mathrm{f}, \min }$ as the $(\mathrm{POC} / \mathrm{EC})_{\mathrm{f}}$ to estimate $\mathrm{POC}_{\mathrm{f}}$. Due to the limited number of samples for ${ }^{14} \mathrm{C}$ analysis, the measured lowest $(\mathrm{OC} / \mathrm{EC})_{\mathrm{f}}$ ratios may be higher than the ratios for the whole sampling period, which will result in an overestimation of $\mathrm{POC}_{\mathrm{f}}$. It is necessary to evaluate $(\mathrm{OC} / \mathrm{EC})_{\mathrm{f}, \min }$ ratios for the whole sampling period. The evaluation method is described in the Supplement. In the same way, primary OC from non-fossil sources $\left(\mathrm{POC}_{\mathrm{nf}}\right)$ can be calculated from $\mathrm{EC}_{\mathrm{nf}}$ and lowest $(\mathrm{OC} / \mathrm{EC})_{\mathrm{nf}}$ ratios; therefore concentrations of secondary $\mathrm{OC}$ from fossil sources $\left(\mathrm{SOC}_{\mathrm{f}}\right)$, non-fossil sources $\left(\mathrm{SOC}_{\mathrm{nf}}\right)$, and $\mathrm{OC}$ from cooking $\left(\mathrm{OC}_{\mathrm{ck}}\right)$ can be obtained by the equations in Table 1. The averaged source apportionment results are presented in Table 4.

Primary fossil-derived OC is mainly from coal combustion and traffic emissions in China. However, it cannot be distinguished by ${ }^{14} \mathrm{C}$ analysis. OC/EC ratios from coal combustion and traffic emissions are dependent on various factors, such as the types of coal, stoves, engines, the vehicle operating modes, and test method. Typical OC/EC ratios of coal combustion and traffic emissions in Beijing are $2.38 \pm 0.44$ and $0.85 \pm 0.16$, respectively (Ni et al., 2018). An upper limit of POC from traffic emissions $\left(\mathrm{POC}_{\mathrm{tr}}\right)$ can be obtained by multiplying $\mathrm{EC}_{\mathrm{f}}$ by the $(\mathrm{OC} / \mathrm{EC})_{\text {tr }}$ ratio $(0.85 \pm 0.16)$, considering all $\mathrm{EC}_{\mathrm{f}}$ to come from traffic emissions. A lower limit of POC from coal combustion $\left(\mathrm{POC}_{\mathrm{cc}}\right)$ is obtained by 
Table 4. Source contribution estimates $\left(\mu \mathrm{g} \mathrm{m}^{-3}\right)$ for OC at IAP and PG in winter and summer.

\begin{tabular}{|c|c|c|c|c|c|c|c|c|}
\hline \multirow[t]{2}{*}{ Sources } & \multicolumn{3}{|c|}{ Winter } & \multicolumn{3}{|c|}{ Winter } & \multicolumn{2}{|c|}{ Summer } \\
\hline & $\begin{array}{l}\text { IAP haze } \\
\quad(n=5)\end{array}$ & $\begin{array}{r}\text { IAP non-haze } \\
(n=2)\end{array}$ & $\begin{array}{l}\text { Winter } \\
(n=7)\end{array}$ & $\begin{array}{l}\text { PG haze } \\
(n=5)\end{array}$ & $\begin{array}{r}\text { PG non-haze } \\
(n=2)\end{array}$ & $\begin{array}{l}\text { Winter } \\
(n=7)\end{array}$ & $\begin{array}{r}\text { IAP } \\
(n=6)\end{array}$ & $\begin{array}{r}\text { PG } \\
(n=5)\end{array}$ \\
\hline \multicolumn{9}{|l|}{ EG method results } \\
\hline Fossil-derived $\mathrm{POC}\left(\mathrm{POC}_{\mathrm{f}}\right)$ & $13.5 \pm 3.9$ & $3.0 \pm 3.5$ & $10.5 \pm 6.2$ & $20.4 \pm 2.5$ & $5.0 \pm 1.3$ & $16.0 \pm 7.8$ & $2.3 \pm 0.8$ & $3.3 \pm 1.9$ \\
\hline Biomass burning $\left(\mathrm{OC}_{\mathrm{bb}}\right)$ & $3.4 \pm 0.9$ & $1.2 \pm 0.9$ & $2.7 \pm 1.3$ & $6.1 \pm 1.7$ & $1.9 \pm 0.5$ & $4.8 \pm 2.4$ & $0.6 \pm 0.7$ & $2.0 \pm 0.8$ \\
\hline Cooking $\left(\mathrm{OC}_{\mathrm{ck}}\right)$ & $1.3 \pm 0.5$ & $0.4 \pm 0.7$ & $1.1 \pm 0.7$ & $6.8 \pm 3.7$ & $3.0 \pm 0.7$ & $5.8 \pm 3.6$ & $1.1 \pm 0.4$ & $0.9 \pm 0.4$ \\
\hline Fossil-derived SOC $\left(\mathrm{SOC}_{\mathrm{f}}\right)$ & $9.5 \pm 3.5$ & $3.3 \pm 1.3$ & $7.7 \pm 4.2$ & $16.8 \pm 10.4$ & $4.6 \pm 2.6$ & $13.3 \pm 10.4$ & $2.0 \pm 0.9$ & $2.1 \pm 1.5$ \\
\hline Non-fossil-derived SOC ( $\left.\mathrm{SOC}_{\mathrm{nf}}\right)$ & $6.2 \pm 2.1$ & $1.5 \pm 1.0$ & $4.8 \pm 2.9$ & $11.9 \pm 9.2$ & $1.9 \pm 1.0$ & $9.1 \pm 9.0$ & $2.2 \pm 2.1$ & $3.1 \pm 3.1$ \\
\hline \multicolumn{9}{|l|}{ CMB results } \\
\hline Gasoline vehicle & $2.8 \pm 1.2$ & $1.4 \pm 0.2$ & $2.4 \pm 1.2$ & $1.6 \pm 1.1$ & $0.5 \pm 0.2$ & $1.3 \pm 1.0$ & $0.4 \pm 0.1$ & $0.1 \pm 0.0$ \\
\hline Diesel vehicle & $1.3 \pm 2.1$ & $0.0 \pm 0.0$ & $0.9 \pm 1.8$ & $11.4 \pm 3.9$ & $1.9 \pm 1.5$ & $8.7 \pm 5.7$ & $0.1 \pm 0.2$ & $0.6 \pm 0.3$ \\
\hline Industrial CC & $5.5 \pm 3.9$ & $0.6 \pm 0.3$ & $4.1 \pm 4.0$ & $4.9 \pm 2.4$ & $1.6 \pm 0.2$ & $4.0 \pm 2.5$ & $2.1 \pm 0.4$ & $4.2 \pm 2.6$ \\
\hline Residential CC & $5.7 \pm 4.8$ & $2.1 \pm 2.3$ & $4.6 \pm 4.4$ & $8.6 \pm 4.7$ & $3.3 \pm 1.4$ & $7.1 \pm 4.7$ & $0.2 \pm 0.1$ & $0.4 \pm 0.2$ \\
\hline Vegetative detritus & $0.1 \pm 0.1$ & $0.1 \pm 0.0$ & $0.1 \pm 0.1$ & $3.3 \pm 4.7$ & $0.5 \pm 0.3$ & $2.5 \pm 4.1$ & $0.2 \pm 0.1$ & $0.3 \pm 0.3$ \\
\hline Biomass burning & $5.5 \pm 1.9$ & $1.8 \pm 1.4$ & $4.4 \pm 2.5$ & $11.6 \pm 4.3$ & $3.0 \pm 0.8$ & $9.2 \pm 5.5$ & $0.6 \pm 0.8$ & $1.2 \pm 0.7$ \\
\hline Cooking & $3.6 \pm 3.3$ & $0.7 \pm 0.5$ & $2.8 \pm 3.1$ & $0.2 \pm 0.2$ & $0.6 \pm 0.1$ & $0.3 \pm 0.3$ & $0.6 \pm 0.3$ & $0.6 \pm 0.4$ \\
\hline Other OC & $9.4 \pm 3.6$ & $2.7 \pm 2.6$ & $7.4 \pm 5.7$ & $20.2 \pm 7.4$ & $5.0 \pm 2.3$ & $15.9 \pm 9.6$ & $4.0 \pm 2.2$ & $4.1 \pm 2.5$ \\
\hline Total OC & $33.8 \pm 8.6$ & $9.4 \pm 7.4$ & $26.8 \pm 14.2$ & $62.0 \pm 19.4$ & $16.4 \pm 6.1$ & $48.9 \pm 27.3$ & $8.3 \pm 3.2$ & $11.5 \pm 4.9$ \\
\hline
\end{tabular}

CMB results are from Wu et al. (2020) and Xu et al. (2021). CC: coal combustion; other OC is calculated by subtracting seven primary sources of OC from total measured OC.

subtracting $\mathrm{POC}_{\text {tr }}$ from $\mathrm{POC}_{\mathrm{f}}$. Such calculation shows that $\mathrm{POC}_{\mathrm{cc}}$ dominated $\mathrm{POC}$ at both sites in winter and summer campaigns. The maximum contribution of $\mathrm{POC}_{\text {tr }}$ to $\mathrm{OC}$ was $7.3 \%$ and $5.7 \%$ in winter and $6.8 \%$ and $8.9 \%$ in summer, for IAP and PG, respectively, and $\mathrm{POC}_{\mathrm{cc}}$ contributed at least $28.5 \%$ and $28.4 \%$ to OC for IAP and PG in winter and $22.2 \%$ and $20.1 \%$ in summer.

This is a relatively crude method for source apportionment of primary OC from fossil and non-fossil sources. Ni et al. $(2018,2019)$ reported $\delta^{13} \mathrm{C}$ signatures of biomass burning, coal combustion, and traffic emissions, as well as the $\mathrm{OC} / \mathrm{EC}$ ratios from previous literature. By combining stable carbon isotopic composition analysis of EC with ${ }^{14} \mathrm{C}$ analysis, the proportions of coal combustion and traffic emission to EC can be derived using Bayesian statistics. The introduction of stable carbon isotopic analysis is suggested as a way to improve our EG method.

Further comparisons with results from application of a CMB method and from application of PMF to ACSM data were conducted to understand the uncertainties in source apportionment from different methods. The source contributions to OC at the IAP and PG sites in winter and summer from the CMB model (Xu et al., 2021; Wu et al., 2020) are presented in Table 4. In brief, seven primary OC sources were apportioned, including emissions from vegetative detritus, biomass burning, cooking, gasoline vehicles, diesel engines, industrial coal combustion, and residential coal combustion, along with other (secondary) OC. Among these sources, coal combustion (the total of residential and industrial coal combustion) accounted for $32.6 \%$ to OC at IAP in winter and $40.0 \%$ to OC at PG in summer, while other OC dominated
$\mathrm{OC}$ at IAP in summer and at PG in winter, with contributions of $48.2 \%$ and $32.5 \%$, respectively.

For comparison, OC from gasoline vehicles, diesel engines, industrial coal combustion, and residential coal combustion resolved by the CMB model is summed up as $\mathrm{POC}_{\mathrm{f}}$, and $\mathrm{OC}$ from vegetative detritus, biomass burning, and cooking is summed up as $\mathrm{POC}_{\mathrm{nf}}$. Correlations of different $\mathrm{OC}$ sources from the extended Gelencsér method (EG method) and from the CMB model are shown in Fig. 5. Good correlations were found for $\mathrm{POC}_{\mathrm{f}}, \mathrm{POC}_{\mathrm{nf}}, \mathrm{SOC}$, and $\mathrm{OC}_{\mathrm{bb}}$, despite the combination of sites and seasons $\left(R^{2}=0.96,0.74,0.85\right.$, and 0.91). The EG method reported lower $\mathrm{POC}_{\mathrm{f}}, \mathrm{POC}_{\mathrm{nf}}$, and $\mathrm{OC}_{\mathrm{bb}}$ values than those from $\mathrm{CMB}$, with slopes of $0.77,0.66$, and 0.53 , respectively. More specifically, $\mathrm{OC}_{\mathrm{bb}}$ by the EG method is $51 \%$ of that by CMB in winter but 1.33 times higher than CMB in summer (Fig. S6 in the Supplement). The main discrepancy within the apportionment of $\mathrm{OC}_{\mathrm{bb}}$ is caused by different parameters for the calculations. As the CMB model used source profiles from three major types of cereal straw (wheat, corn, and rice) and two types of wood (pine and mixed wood), it may lead to an overestimation of $\mathrm{OC}$ from straw burning. Closer values of $\mathrm{POC}_{\mathrm{nf}}$ and SOC were found between the two methods in summer, when samples almost all belong to the non-haze period (Figs. S6 and S7 in the Supplement). This indicates that the EG method may perform better when $\mathrm{OC}$ concentrations are low. $\mathrm{Al}-$ though poor agreement of $\mathrm{OC}_{\mathrm{ck}}$ was found between the $\mathrm{EG}$ method and the CMB model, the former correlated better with results from the application of PMF to AMS/ACSM data (slope $=0.74, R^{2}=0.61$ ). It has previously been shown that discrepancies exist between the CMB and PMF model 

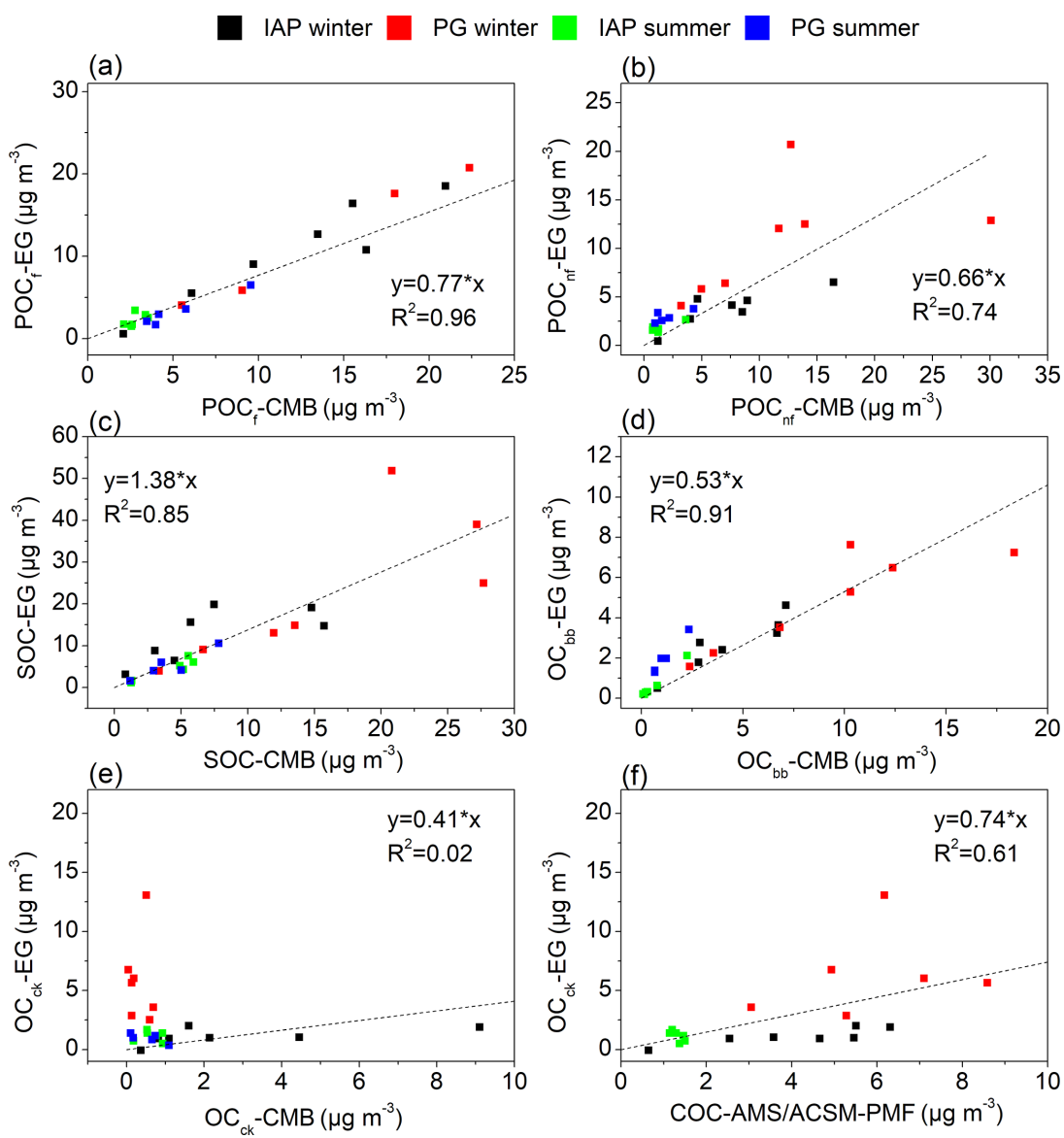

Figure 5. Correlations of OC sources from the extended Gelencsér method with those from the CMB model. EG denotes the extended Gelencsér method, (a) primary OC from fossil sources, (b) primary OC from non-fossil sources, (c) secondary OC, (d) OC from biomass burning, (e) $\mathrm{OC}$ from cooking, (f) correlations of $\mathrm{OC}_{\mathrm{ck}}$ from extended Gelencsér method and AMS/ACSM-PMF model (AMS for IAP and ACSM for PG). Good correlations were found within the apportionments of $\mathrm{POC}_{\mathrm{f}}, \mathrm{POC}_{\mathrm{nf}}$, SOC, and $\mathrm{OC}_{\mathrm{bb}}$ between the $\mathrm{CMB}$ and EG method and large discrepancies of $\mathrm{OC}_{\mathrm{ck}}$. The PMF model did not show certain source apportionment results from fossil, non-fossil, or secondary $\mathrm{OC}$; i.e. only $\mathrm{OC}_{\mathrm{ck}}$ concentrations were compared.

in the quantification of $\mathrm{OC}_{\mathrm{ck}}$. ACSM-PMF may overestimate $\mathrm{OC}_{\mathrm{ck}}$ by approximately 2 times (Reyes-Villegas, et al., 2018; Yin et al., 2015), whereas CMB may not be sensitive enough to the source profile of cooking aerosols (Abdullahi et al., 2018). Overall, the EG method resolves primary and secondary sources of OC well.

Time variations of OC fractions by the EG method and their average contributions are shown in Fig. $6 . \mathrm{POC}_{\mathrm{f}}$ was the largest contributor to $\mathrm{OC}$ at both sites through winter and summer. Comparable contributions of $\mathrm{POC}_{\mathrm{f}}$ were observed at the urban and rural sites, which reached to $35.8 \pm 10.5 \%$ and $34.1 \pm 8.7 \%$ in wintertime and fell to $28.9 \pm 7.4 \%$ and $29.1 \pm 9.4 \%$ in summer, respectively. Pronounced $\mathrm{POC}_{\mathrm{f}}$ in wintertime implied a significant elevation of coal combustion and traffic emissions. Fossil and non-fossil sources of SOC are distinguished by the EG method in this study for the first time. Average contributions to $\mathrm{OC}$ from $\mathrm{SOC}_{\mathrm{f}}$ are higher in winter. They decreased from $32.0 \pm 12.5 \%$ to $25.2 \pm 7.6 \%$ at IAP and from $25.2 \pm 10.4 \%$ to $21.0 \pm 14.4 \%$ at PG from winter to summer. The contributions of $\mathrm{SOC}_{\mathrm{nf}}$ are slightly greater in summer $(18.0 \pm 2.9 \%, 22.0 \pm 17.6 \%$ for IAP in winter and summer and $16.9 \pm 10.8 \%, 21.7 \pm 16.1 \%$ for PG in winter and summer, respectively). Significant contributions of $\mathrm{SOC}_{\mathrm{f}}$ in the winter sampling period indicated a greater fraction of $\mathrm{OC}_{\mathrm{f}}$ from ageing and oxidation. The elevated contributions of $\mathrm{SOC}_{\mathrm{nf}}$ (as a percentage) in the summer sampling period may be assigned to the reduced coal combustion and enhanced biogenic-derived SOC formation. Similar variations of $\mathrm{SOC}_{\mathrm{f}}$ and $\mathrm{OC}_{\mathrm{onf}}$ (all OC from non-fossil sources excluding $\mathrm{OC}_{\mathrm{bb}}$ ) between winter and summer were found in the urban area of Beijing by Zhang et al. (2016). The total SOC accounts for $50.0 \pm 12.3 \%$ and $42.0 \pm 11.7 \%$ of OC for IAP and PG site in winter, demonstrating the important role of secondary formation processes, especially at the urban site. The average contributions of $\mathrm{OC}_{\mathrm{ck}}$ were $3.6 \pm 2.7 \%$ and $13.4 \pm 5.8 \%$ in winter for IAP and PG and 

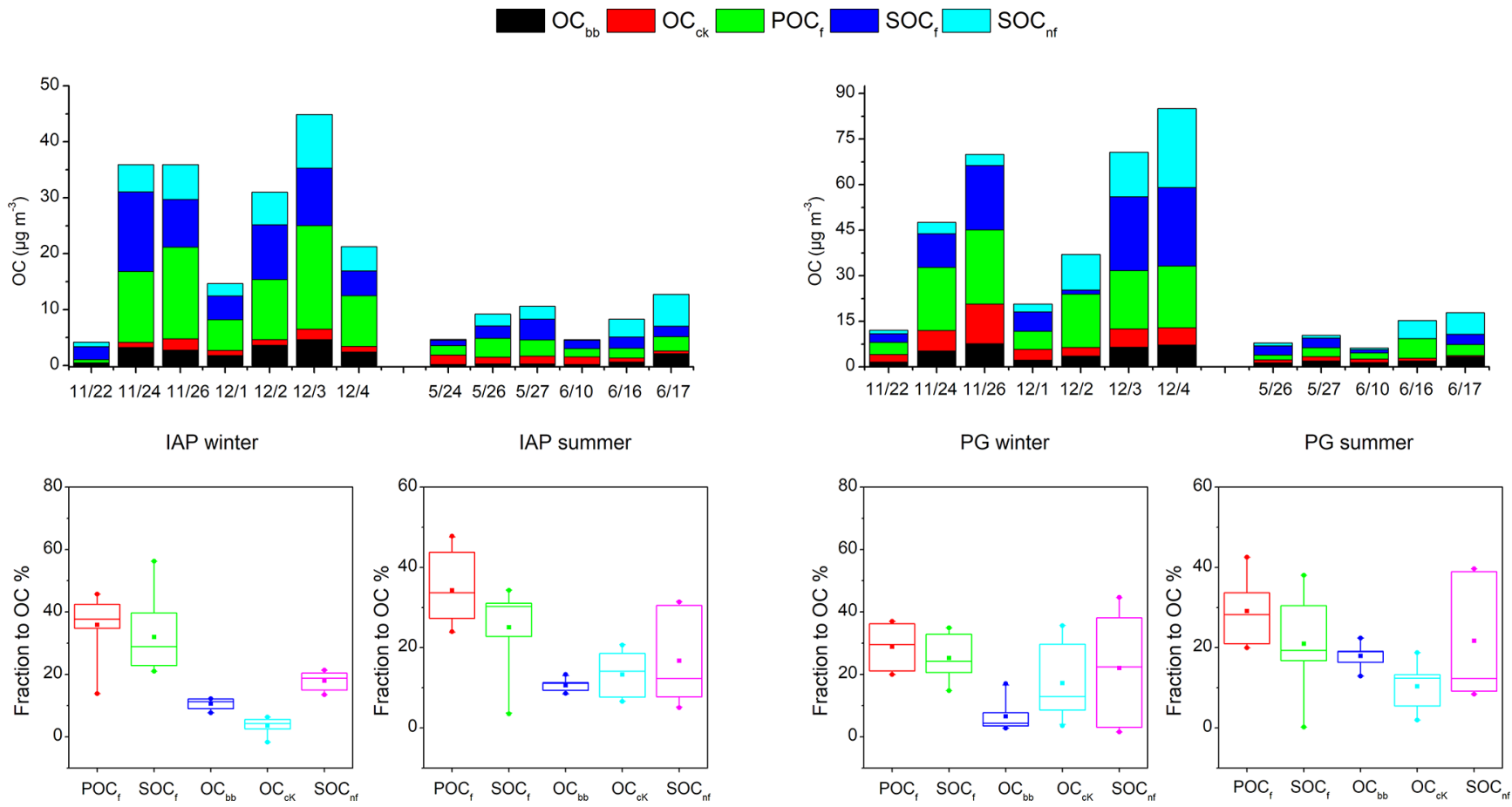

Figure 6. Time variations of $\mathrm{OC}$ source apportionment results by the extended Gelencsér method (upper) and the fractions of each source (i.e., $\mathrm{POC}_{\mathrm{f}}, \mathrm{SOC}_{\mathrm{f}}, \mathrm{OC}_{\mathrm{bb}}, \mathrm{OC}_{\mathrm{ck}}$, and $\mathrm{SOC}_{\mathrm{nf}}$ ) in $\mathrm{OC}$ based on the extended Gelencsér method (lower). f: fossil fuel sources, nf: non-fossil sources, bb: biomass burning, ck: cooking. The box denotes the 25th (lower line), 50th (middle line), and 75th (top line) percentiles; the solid squares within the box denote the mean values; the end of the vertical bars represents the 10th (below the box) and 90th (above the box) percentiles; and the solid dots denote maximum and minimum values.

$17.4 \pm 12.5 \%$ and $10.4 \pm 6.7 \%$ in summer, close to those estimated in previous studies (19 $\pm 4 \%$; Zhang et al., 2017). The slightly lower value of the $\mathrm{OC}_{\mathrm{ck}}$ contribution in winter at the IAP site (Fig. 5) was due to $\mathrm{OC}_{\mathrm{bb}}$ being the overwhelming contributor to $\mathrm{POC}_{\mathrm{nf}}$.

In the winter sampling campaign at IAP, $\mathrm{POC}_{\mathrm{f}}$ was the biggest contributor to OC, followed by $\mathrm{SOC}_{\mathrm{f}}$. Both of them were significantly enhanced during haze periods, while the non-fossil fractions, $\mathrm{OC}_{\mathrm{bb}}, \mathrm{OC}_{\mathrm{ck}}$, and $\mathrm{SOC}_{\mathrm{nf}}$, did not show much difference between haze and non-haze periods. This implies the haze pollution at IAP in winter was elevated by the accumulation of coal combustion and traffic emissions under favourable weather conditions. The formation of secondary OC associated with coal combustion and traffic emissions was increased during the haze period. In the winter campaign at $\mathrm{PG}, \mathrm{POC}_{\mathrm{f}}$ and $\mathrm{SOC}_{\mathrm{f}}$ were the top two contributors to OC; however, the contribution of $\mathrm{POC}_{\mathrm{f}}$ and $\mathrm{SOC}_{\mathrm{f}}$ did not increase much in the haze period. In contrast, the fractions of $\mathrm{SOC}_{\mathrm{nf}}$ increased substantially on 3 and 4 December, on which days there were found to be open burning activities in surrounding areas (shown from the fire spots on Fig. S2). This shows that a large proportion of $\mathrm{OC}_{\mathrm{bb}}$ was transformed to secondary $\mathrm{OC}$ during the transport of biomass burning aerosols to the receptor sites. In summer, the sudden increase of the $\mathrm{SOC}_{\mathrm{nf}}$ fraction on 16 and 17 June at both sites was accompanied by an increase of $\mathrm{PM}_{2.5}$ and OC concentrations. This is likely due to the open burning activities in surrounding areas. The enhancement of $(\mathrm{OC} / \mathrm{EC})_{\mathrm{nf}}$ ratios and $\mathrm{WSOC}_{\mathrm{nf}}$ fractions also suggested secondary OC formation through oxidation of primary non-fossil sources. The standard deviations appear small but obscure the marked differences between seasons. Also, the time series in Fig. 6 shows substantial day-to-day variations in the source contributions within a season but still suggests that meteorological drivers play a major role in determining daily concentrations.

\subsubsection{Correlations of WINSOC and WSOC with POC and SOC}

In order to better understand the origins and formation mechanism of OC, the correlations between WINSOC and WSOC and between POC and SOC, $\mathrm{OC}_{\mathrm{bb}}$ and $\mathrm{OC}_{\mathrm{ck}}$ were investigated (Fig. 7). The regression slopes and correlation coefficients among them are summarized in Table S6. $\mathrm{WINSOC}_{\mathrm{f}}$ has usually been seen as a proxy for primary fossil-derived OC in many previous studies (Liu et al., 2016c; Miyazaki et al., 2006), and in our study, WINSOC $_{f}$ correlated well with calculated $\mathrm{POC}_{\mathrm{f}}$ by the EG method $\left(R^{2}\right.$ of $0.97,0.93,0.97$, and 0.82 for IAP and PG in winter and summer, respectively); good correlations were also observed between WINSOC $_{\mathrm{f}}$ and $\mathrm{SOC}_{\mathrm{f}}$, with slopes 

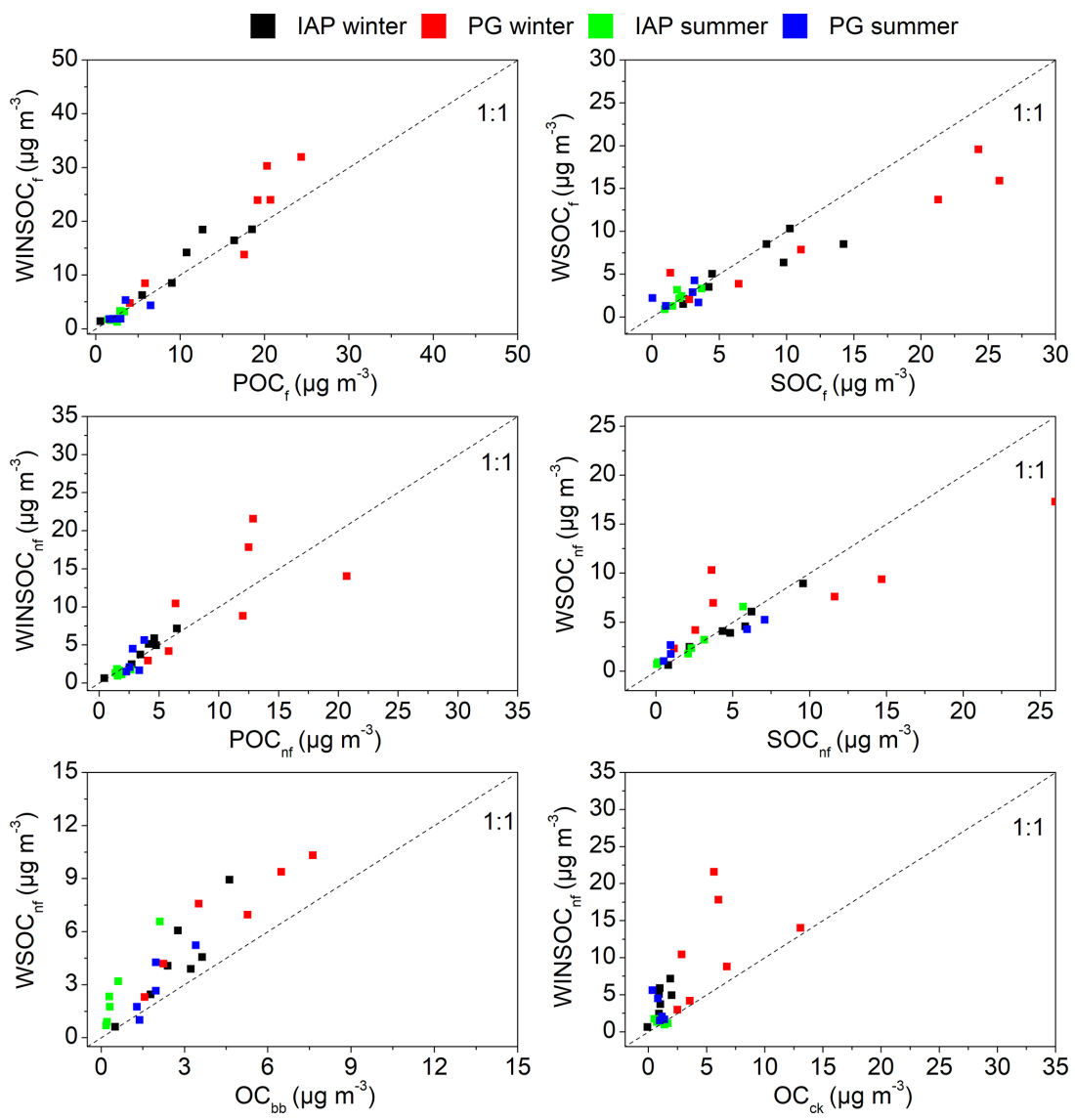

Figure 7. Correlations of WINSOC and WSOC with POC and SOC at IAP and PG sites in winter and summer. The slopes and correlation coefficients are summarized in Table S6.

of $1.54,1.27,0.99$, and 0.99 for IAP and PG in winter and summer (corresponding $R^{2}$ is $0.96,0.89,0.91$, and 0.43). The high WINSOC $\mathrm{f} / \mathrm{SOC}_{\mathrm{f}}$ ratios implied a nonnegligible fraction of $\mathrm{WINSOC}_{\mathrm{f}}$ in $\mathrm{SOC}_{\mathrm{f}}$. Moreover, the ratios of $\mathrm{WINSOC}_{\mathrm{f}} / \mathrm{POC}_{\mathrm{f}}$ decreased from winter to summer compared to the $\mathrm{WSOC}_{\mathrm{f}} / \mathrm{POC}_{\mathrm{f}}$ ratios increasing, indicating a non-negligible fraction of $\mathrm{WSOC}_{\mathrm{f}}$ in $\mathrm{POC}_{\mathrm{f}}$ in summer. $\mathrm{WSOC}_{\mathrm{nf}}$ and $\mathrm{WINSOC}_{\mathrm{nf}}$ show good correlations with $\mathrm{SOC}_{\mathrm{nf}}$, with larger $\mathrm{WINSOC}_{\mathrm{nf}} / \mathrm{SOC}_{\mathrm{nf}}$ ratios in winter. The lower water solubility of $\mathrm{SOC}_{\mathrm{f}}$ and $\mathrm{SOC}_{\mathrm{nf}}$ in winter may be due to them originating from the less oxidized semi-volatile POC from wood burning and anthropogenic emission at low temperatures (Favez et al., 2008; Sciare et al., 2011). Weak photochemical activity would also lead to the formation of less oxidized SOC, which is more water-insoluble (Donahue et al., 2006; Robinson et al., 2007). Significant contributions of WINSOC to SOC have been reported in France (Sciare et al., 2011) and Switzerland (Zhang et al., 2016). $\mathrm{OC}_{\mathrm{bb}}$ correlated well with $\mathrm{WSOC}_{\mathrm{nf}}\left(R^{2}\right.$ of $0.94,0.92$, 0.93 , and 0.93 , at IAP and PG in winter and summer) as it is mainly composed of polar and highly oxygenated compounds (Miyazaki et al., 2006). However, more pronounced WINSOC ${ }_{\mathrm{nf}}$ in $\mathrm{OC}_{\mathrm{bb}}$ was found in winter, especially at the rural site. It seems that more water-insoluble fractions were observed in primary $\mathrm{OC}\left(\mathrm{POC}_{\mathrm{f}}, \mathrm{POC}_{\mathrm{nf}}, \mathrm{OC}_{\mathrm{bb}}\right.$, and $\left.\mathrm{OC}_{\mathrm{ck}}\right)$ at the rural site in both winter and summer. It implies the emitted primary OC at the rural site was probably fresher and hence less aged and oxidized. On the other hand, the source emission profile at rural sites may be different from urban sites, with more heavy-duty diesel trucks with a high content of water-insoluble OC emitted in rural areas.

\section{Conclusions}

Measurements of $\mathrm{PM}_{2.5}, \mathrm{OC}, \mathrm{EC}$, and biomass burning tracers were conducted at both urban and rural sites of Beijing from 10 November to 11 December 2016 and from 22 May to 24 June 2017 , accompanied by the ${ }^{14} \mathrm{C}$ analysis of $25 \mathrm{se}-$ lected samples. On most days, fossil sources dominated EC at IAP and PG in winter and summer, with contributions of $45.9 \%-71.7 \%$ at IAP and $48.2 \%-76.6 \%$ at PG. The fossil sources of OC contribute $34.7 \%-75.0 \%$ and $39.3 \%-66.9 \%$ for IAP and PG, with non-fossil fractions of OC elevated in summer. An extended Gelencsér method using the ${ }^{14} \mathrm{C}$ measurements was applied for the first time to estimate fos- 
sil and non-fossil sources of primary and secondary OC, as well as $\mathrm{OC}$ from biomass burning and cooking $\left(\mathrm{POC}_{\mathrm{f}}\right.$, $\mathrm{SOC}_{\mathrm{f}}, \mathrm{POC}_{\mathrm{nf}}, \mathrm{SOC}_{\mathrm{nf}}, \mathrm{OC}_{\mathrm{bb}}$, and $\mathrm{OC}_{\mathrm{ck}}$, respectively). Fossilderived $P O C$ is a major contributor during winter and summer at both sites. Fossil-derived SOC contributed more in winter, especially at the urban site, with average contributions (to OC) of $32.0 \pm 12.5 \%$ and $25.2 \pm 7.6 \%$ for IAP and $25.2 \pm 10.4 \%$ and $21.0 \pm 14.4 \%$ for PG in winter and summer, respectively. The contribution of $\mathrm{SOC}_{\mathrm{nf}}$ increased in summer, which is probably associated with formation from biogenic emissions. A study of relationships among levoglucosan, mannosan, and galactosan showed that biomass burning was mainly from softwood combustion and straw burning. The extended Gelencsér method using ${ }^{14} \mathrm{C}$ data provided a more robust calculation of $\mathrm{OC}_{\mathrm{bb}}$. The contributions of $\mathrm{OC}_{\mathrm{bb}}$ to $\mathrm{OC}$ were $10.6 \pm 1.7 \%$ and $10.4 \pm 1.5 \%$ for IAP and PG in winter and $6.5 \pm 5.2 \%$ and $17.9 \pm 3.5 \%$ for IAP and PG in summer. Correlations among WINSOC and WSOC and POC and SOC showed that WINSOC and WINSOC were the main components of $\mathrm{POC}_{\mathrm{f}}$ and $\mathrm{POC}_{\mathrm{nf}}$, respectively. However, large fractions of WINSOC were found in both $\mathrm{SOC}_{\mathrm{f}}$ and $\mathrm{SOC}_{\mathrm{nf}}$, especially at the rural site, and the contributions of water-insoluble $\mathrm{OC}$ decreased from winter to summer, with more WSOC formed under favourable conditions in summer. Although derived from a limited number of samples, our study reflected the different formation mechanisms of SOC between winter and summer and between the urban and rural area. It also confirms the feasibility of a new approach of direct source apportionment of carbonaceous aerosol, which was found to compare generally well with the commonly used chemical mass balance and AMS/ACSM-PMF methods.

Data availability. Data supporting this publication are openly available from the UBIRA eData repository at https://doi.org/10.25500/edata.bham.00000572 (Harrison et al., 2020).

Supplement. The supplement related to this article is available online at: https://doi.org/10.5194/acp-21-8273-2021-supplement.

Author contributions. ZS and RMH conceived the research. TVV and DL conducted the aerosol sampling and laboratory-based OC/EC analyses. DL and LL carried out the GC-MS analysis. PF supervised GC-MS laboratory work. AV, VM, and GS carried out the ${ }^{14} \mathrm{C}$ analysis. SS and ASHP supervised the ${ }^{14} \mathrm{C}$ analysis. $\mathrm{XW}$ and JX conducted the CMB modelling at PG and IAP sites, respectively. SH conducted the analysis of the extended Gelencsér (EG) method incorporating ${ }^{14} \mathrm{C}$ data. YS provided the AMS-PMF data. SH and DL drafted the paper. DS conducted the PMF modelling.
Competing interests. The authors declare that they have no conflict of interest.

Special issue statement. This article is part of the special issue "In-depth study of air pollution sources and processes within Beijing and its surrounding region (APHH-Beijing) (ACP/AMT interjournal SI)". It is not associated with a conference.

Acknowledgements. We acknowledge the support from Zifa Wang and Jie Li from IAP for hosting the APHH-Beijing campaigns at IAP. We also thank Bill Bloss, Leigh Crilley, and Louisa Kramer from the University of Birmingham, Siyao Yue, Liangfang Wei, Hong Ren, Qiaorong Xie, Wanyu Zhao, Linjie Li, Ping Li, Shengjie Hou, Qingqing Wang, Pingqing Fu, and Yele Sun from the Institute of Atmospheric Physics, Rachel Dunmore, Ally Lewis, Jacqui Hamilton, and James Lee from the University of York, Kebin He and Xiaoting Cheng from Tsinghua University, James Allan and Hugh Coe from the University of Manchester, Yiqun Han and Hanbing Zhang from King's College London, and Tong Zhu from Peking University for providing logistic and scientific support for the field campaigns.

Financial support. This research has been supported by the UK Natural Environment Research Council (NERC; grant nos. NE/N007190/1 and NE/R005281/1) and the Royal Society Advanced Fellowship (grant no. NAF/R1/191220).

Review statement. This paper was edited by Yongjie Li and reviewed by two anonymous referees.

\section{References}

Abdullahi, K. L., Delgado-Saborit, J. M., and Harrison, R. M.: Sensitivity of a Chemical Mass Balance model for $\mathrm{PM}_{2.5}$ to source profiles for differing styles of cooking, Atmos. Environ., 178, 282-285, https://doi.org/10.1016/j.atmosenv.2018.01.046, 2018.

Agrios, K., Salazar, G., Zhang, Y.-L., Uglietti, C., Battaglia, M., Luginbühl, M., Ciobanu, V. G., Vonwiller, M., and Szidat, S.: Online coupling of pure $\mathrm{O}_{2}$ thermo-optical methods $-{ }^{14} \mathrm{C}$ AMS for source apportionment of carbonaceous aerosols, Nucl. Instrum. Meth. B, 361, 288-293, https://doi.org/10.1016/j.nimb.2015.06.008, 2015.

Andreae, M. O. and Merlet, P.: Emission of trace gases and aerosols from biomass burning, Global Biogeochem. Cy., 15, 955-966, https://doi.org/10.1029/2000GB001382, 2001.

Barrett, T. E., Robinson, E. M., Usenko, S., and Sheesley, R. J.: Source contributions to wintertime elemental and organic carbon in the Western Arctic based on radiocarbon and tracer apportionment, Environ. Sci. Technol., 49, 11631-11639., https://doi.org/10.1021/acs.est.5b03081, 2015.

Bernardoni, V., Calzolai, G., Chiari, M., Fedi, M., Lucarelli, F., Nava, S., Piazzalunga, A., Riccobono, F., Taccetti, F., Valli, G., and Vecchi, R.: Radiocarbon analysis on organic and el- 
emental carbon in aerosol samples and source apportionment at an urban site in Northern Italy, J. Aerosol Sci., 56, 88-99, https://doi.org/10.1016/j.jaerosci.2012.06.001, 2013.

Cai, T., Zhang, Y., Fang, D., Shang, J., Zhan, Y., and Zhang, Y.: Chinese vehicle emissions characteristic testing with small sample size: Results and comparison, Atmos. Pollut. Res., 8, 154-163, https://doi.org/10.1016/j.apr.2016.08.007, 2017.

Castro, L., Pio, C., Harrison, R. M., and Smith, D.: Carbonaceous aerosol in urban and rural European atmospheres: Estimation of secondary organic carbon concentrations, Atmos. Environ., 33, 2771-2781, https://doi.org/10.1016/S1352-2310(98)003318, 1999.

Chen, H. Y., Yin, S. S., Li, X., Wang, J., and Zhang, R. Q.: Analyses of biomass burning contribution to aerosol in Zhengzhou during wheat harvest season in 2015, Atmos. Res., 207, 62-73, https://doi.org/10.1016/j.atmosres.2018.02.025, 2018.

Chen, J. M., Li, C. L., Ristovski, Z., Milic, A., Gu, Y. T., Islam, M. S., Wang, S. X., Hao, J. M., Zhang, H. F., He, C. R., Guo, H., Fu, H. B., Miljevic, B., Morawska, L., Thai, P., Fat, L., Pereira, G., Ding, A. J., Huang, X., and Dumka, U. C.: A review of biomass burning: Emissions and impacts on air quality, health and climate in China, Sci. Total Environ., 579, 1000-1034, https://doi.org/10.1016/j.scitotenv.2016.11.025, 2017.

Cheng, Y., Engling, G., He, K.-B., Duan, F.-K., Ma, Y.-L., Du, Z.Y., Liu, J.-M., Zheng, M., and Weber, R. J.: Biomass burning contribution to Beijing aerosol, Atmos. Chem. Phys., 13, 77657781, https://doi.org/10.5194/acp-13-7765-2013, 2013.

Chow, J. C., Watson, J. G., Lu, Z., Lowenthal, D. H., Frazier, C. A., Solomon, P. A., Thuillier, R. H., and Magliano, K.: Descriptive analysis of $\mathrm{PM}_{2.5}$ and $\mathrm{PM}_{10}$ at regionally representative locations during SJVAQS/AUSPEX, Atmos. Environ., 30, 20792112, https://doi.org/10.1016/1352-2310(95)00402-5, 1996.

Chow, J. C., Watson, J. G., Crow, D., Lowenthal, D. H., and Merrifield, T.: Comparison of IMPROVE and NIOSH carbon measurements, Aerosol Sci. Tech., 34, 23-34, https://doi.org/10.1080/02786820119073, 2001.

Donahue, N. M., Robinson, A. L., Stanier, C. O., and Pandis, S. N.: Coupled Partitioning, Dilution, and Chemical Aging of Semivolatile Organics, Environ. Sci. Technol., 40, 2635-2643, https://doi.org/10.1021/es052297c, 2006.

Favez, O., Sciare, J., Cachier, H., Alfaro, S. C., and Abdelwahab, M. M.: Significant formation of water-insoluble secondary organic aerosols in semi-arid urban environment, Geophys. Res. Lett., 35, L15801, https://doi.org/10.1029/2008g1034446, 2008.

Fu, P. Q., Kawamura, K., Chen, J., Li, J., Sun, Y. L., Liu, Y., Tachibana, E., Aggarwal, S. G., Okuzawa, K., Tanimoto, H., Kanaya, Y., and Wang, Z. F.: Diurnal variations of organic molecular tracers and stable carbon isotopic composition in atmospheric aerosols over Mt. Tai in the North China Plain: an influence of biomass burning, Atmos. Chem. Phys., 12, 8359-8375, https://doi.org/10.5194/acp-12-8359-2012, 2012.

Fu, P. Q., Zhuang, G. S., Sun, Y. L., Wang, Q. Z., Chen, J., Ren, L. J., Yang, F., Wang, Z. F., Pan, X. L., Li, X. D., and Kawamura, K.: Molecular markers of biomass burning, fungal spores and biogenic SOA in the Taklimakan desert aerosols, Atmos. Environ., 130, 64-73, https://doi.org/10.1016/j.atmosenv.2015.10.087, 2016.

Gelencsér, A., May, B., Simpson, D., Sánchez-Ochoa, A., KasperGiebl, A., Puxbaum, H., Caseiro, A., Pio, C., and Legrand,
M.: Source apportionment of $\mathrm{PM}_{2.5}$ organic aerosol over Europe: Primary/secondary, natural/anthropogenic, and fossil/biogenic origin, J. Geophys. Res.-Atmos., 112, D23S04, https://doi.org/10.1029/2006JD008094, 2007.

Gray, H. A. and Cass, G. R.: Source contributions to atmospheric fine carbon particle concentrations, Atmos. Environ., 32, 38053825, https://doi.org/10.1016/S1352-2310(97)00446-9, 1998.

Han, Y. M., Chen, L.-W. A., Huang, R.-J., Chow, J. C., Watson, J. G., Ni, H. Y., Liu, S. X., Fung, K. K., Shen, Z. X., Wei, C., Wang, Q. Y., Tian, J., Zhao, Z. Z., Prévôt, A. S. H., and Cao, J. J.: Carbonaceous aerosols in megacity Xi'an, China: Implications of thermal/optical protocols comparison, Atmos. Environ., 132, 58-68, https://doi.org/10.1016/j.atmosenv.2016.02.023, 2016.

Harrison, R. M., Hou, S., and Xu, J.: Research data supporting "Source Apportionment of Carbonaceous Aerosols in Beijing with Radiocarbon and Organic Tracers: Insight into the Differences between Urban and Rural Sites", University of Birmingham [data set], https://doi.org/10.25500/edata.bham.00000572, 2020.

He, K., Yang, F., Ma, Y., Zhang, Q., Yao, X., Chan, C. K., Cadle, S., Chan, T., and Mulawa, P.: The characteristics of $\mathrm{PM}_{2.5}$ in Beijing, China, Atmos. Environ., 35, 4959-4970, https://doi.org/10.1016/S1352-2310(01)00301-6, 2001.

Hou, B.-D., Tang, X., Ma, C., Liu, L., Wei, Y.-M., Liao, H.: Cooking fuel choice in rural China: results from microdata, J. Clean. Prod., 142, 538-547, https://doi.org/10.1016/j.jclepro.2016.05.031, 2017.

Huang, R.-J., Zhang, Y., Bozzetti, C., Ho, K.-F., Cao, J.-J., Han, Y., Daellenbach, K. R., Slowik, J. G., Platt, S. M., Canonaco, F., Zotter, P., Wolf, R., Pieber, S. M., Bruns, E. A., Crippa, M., Ciarelli, G., Piazzalunga, A., Schwikowski, M., Abbaszade, G., SchnelleKreis, J., Zimmermann, R., An, Z., Szidat, S., Baltensperger, U., Haddad, I. E., and Prévôt, A. S. H.: High secondary aerosol contribution to particulate pollution during haze events in China, Nature, 514, 218-222, https://doi.org/10.1038/nature13774, 2014.

Jimenez, J. L., Canagaratna, M. R., Donahue, N. M., Prevot, A. S. H., Zhang, Q., Kroll, J. H., DeCarlo, P. F., Allan, J. D., Coe, H., Ng, N. L., Aiken, A. C., Docherty, K. S., Ulbrich, I. M., Grieshop, A. P., Robinson, A. L., Duplissy, J., Smith, J. D., Wilson, K. R., Lanz, V. A., Hueglin, C., Sun, Y. L., Tian, J., Laaksonen, A., Raatikainen, T., Rautiainen, J., Vaattovaara, P., Ehn, M., Kulmala, M., Tomlinson, J. M., Collins, D. R., Cubison, M. J., Dunlea, E. J., Huffman, J. A., Onasch, T. B., Alfarra, M. R., Williams, P. I., Bower, K., Kondo, Y., Schneider, J., Drewnick, F., Borrmann, S., Weimer, S., Demerjian, K., Salcedo, D., Cottrell, L., Griffin, R., Takami, A., Miyoshi, T., Hatakeyama, S., Shimono, A., Sun, J. Y., Zhang, Y. M., Dzepina, K., Kimmel, J. R., Sueper, D., Jayne, J. T., Herndon, S. C., Trimborn, A. M., Williams, L. R., Wood, E. C., Middlebrook, A. M., Kolb, C. E., Baltensperger, U., and Worsnop, D. R.: Evolution of organic aerosols in the atmosphere, Science, 326, 1525-1529, https://doi.org/10.1126/science.1180353, 2009.

Kang, M., Ren, L., Ren, H., Zhao, Y., Kawamura, K., Zhang, H., Wei, L., Sun, Y., Wang, Z., and Fu, P.: Primary biogenic and anthropogenic sources of organic aerosols in Beijing, China: Insights from saccharides and n-alkanes, Environ. Pollut., 243, 1579-1587, https://doi.org/10.1016/j.envpol.2018.09.118, 2018.

Kawamura, K., Izawa, Y., Mochida, M., and Shiraiwa, T.: Ice core records of biomass burning tracers (levoglucosan and de- 
hydroabietic, vanillic and p-hydroxybenzoic acids) and total organic carbon for past 300 years in the Kamchatka Peninsula, Northeast Asia, Geochim. Cosmochim. Ac., 99, 317-329, https://doi.org/10.1016/j.gca.2012.08.006, 2012.

Levin, I., Naegler, T., Kromer, B., Diehl, M., Francey, R., GomezPelaez, A., Steele, P., Wagenbach, D., Weller, R., and Worthy, D.: Observations and modelling of the global distribution and long-term trend of atmospheric ${ }^{14} \mathrm{CO}_{2}$, Tellus B, 62, 26-46, https://doi.org/10.1111/j.1600-0889.2009.00446.x, 2010.

Lewis, C. W., Klouda, G. A., and Ellenson W. D.: Radiocarbon measurement of the biogenic contribution to summertime $\mathrm{PM}_{2.5} \mathrm{am}$ bient aerosol in Nashville, TN, Atmos. Environ., 38, 6053-6061, https://doi.org/10.1080/02786820500521007, 2004.

Li, L. J., Ren, L. J., Ren, H., Yue, S. Y., Xie, Q. R., Zhao, W. Y., Kang, M. J., Li, J., Wang, Z. F., Sun, Y. L., and Fu, P. Q.: Molecular Characterization and Seasonal Variation in Primary and Secondary Organic Aerosols in Beijing, China, J. Geophys. Res.-Atmos., 123, 12394-12412, https://doi.org/10.1029/2018JD028527, 2018.

Li, X., Chen, M., Le, H. P., Wang, F., Guo, Z., Iinuma, Y., Chen, J., and Herrmann, H.: Atmospheric outflow of $\mathrm{PM}_{2.5}$ saccharides from megacity Shanghai to East China Sea: Impact of biological and biomass burning sources, Atmos. Environ., 143, 1-14, https://doi.org/10.1016/j.atmosenv.2016.08.039, 2016.

Liu, D., Li, J., Zhang, Y. L., Xu, Y., Liu, X., Ding, P., Shen, C. D., Chen, Y. J., Tian, C. G., and Zhang, G.: The use of levoglucosan and radiocarbon for source apportionment of $\mathrm{PM}_{2.5}$ carbonaceous aerosols at a background site in east China, Environ. Sci. Technol., 47, 10454-10461, https://doi.org/10.1021/es401250k, 2013

Liu, D., Li, J., Cheng, Z., Zhong, G., Zhu, S., Ding, P., Shen, C., Tian, C., Chen, Y., Zhi, G., and Zhang, G.: Sources of nonfossil-fuel emissions in carbonaceous aerosols during early winter in Chinese cities, Atmos. Chem. Phys., 17, 11491-11502, https://doi.org/10.5194/acp-17-11491-2017, 2017.

Liu, D., Vonwiller, M., Li, J., Liu, J., Szidat, S., Zhang, Y., Tian, C., Chen, Y., Cheng, Z., Zhong, G., Fu, P., and Zhang, G.: Fossil and non-fossil fuel sources of organic and elemental carbon aerosols in Beijing, Shanghai and Guangzhou: Seasonal carbon-source variation, Aerosol Air Qual. Res., 20, 2495-2506, https://doi.org/10.4209/aaqr.2019.12.0642, 2020.

Liu, J. W., Mo, Y. Z., Li, J., Liu, D., Shen, C. D., Ding, P., Jiang, H. Y., Cheng, Z. N., Zhang, X. Y., Tian, C. G., Chen, Y. J., and Zhang, G.: Radiocarbon-derived source apportionment of fine carbonaceous aerosols before, during, and after the 2014 Asia-Pacific Economic Cooperation (APEC) summit in Beijing, China, J. Geophys. Res.-Atmos., 121, 4177-4187, https://doi.org/10.1002/2016JD024865, 2016a.

Liu, J. W., Li, J., Vonwiller, M., Liu, D., Cheng, H. R., Shen, K. J., Salazar, G., Agrios, K., Zhang, Y. L., He, Q. F., Ding, X., Zhong, G. C., Wang, X. M., Szidat, S., and Zhang, G.: The importance of non-fossil sources in carbonaceous aerosols in a megacity of central China during the 2013 winter haze episode: A source apportionment constrained by radiocarbon and organic tracers, Atmos. Environ., 144, 60-68, https://doi.org/10.1016/j.atmosenv.2016.08.068, 2016 b.

Liu, J., Li, J., Liu, D., Ding, P., Shen, C., Mo, Y., Wang, X., Luo, C., Cheng, Z., Szidat, S., Zhang, Y., Chen, Y., and Zhang, G.: Source apportionment and dynamic changes of carbonaceous aerosols during the haze bloom-decay process in China based on radiocarbon and organic molecular tracers, Atmos. Chem. Phys., 16 2985-2996, https://doi.org/10.5194/acp-16-2985-2016, 2016c.

Minguillón, M. C., Perron, N., Querol, X., Szidat, S., Fahrni, S. M., Alastuey, A., Jimenez, J. L., Mohr, C., Ortega, A. M., Day, D. A., Lanz, V. A., Wacker, L., Reche, C., Cusack, M., Amato, F., Kiss, G., Hoffer, A., Decesari, S., Moretti, F., Hillamo, R., Teinilä, K., Seco, R., Peñuelas, J., Metzger, A., Schallhart, S., Müller, M., Hansel, A., Burkhart, J. F., Baltensperger, U., and Prévôt, A. S. H.: Fossil versus contemporary sources of fine elemental and organic carbonaceous particulate matter during the DAURE campaign in Northeast Spain, Atmos. Chem. Phys., 11, 12067 12084, https://doi.org/10.5194/acp-11-12067-2011, 2011.

Miyazaki, Y., Kondo, Y., Takegawa, N., Komazaki, Y., Fukuda, M., Kawamura, K., Mochida, M., Okuzawa, K., and Weber, R. J.: Time-resolved measurements of water-soluble organic carbon in Tokyo, J. Geophys. Res.-Atmos., 111, D23206, https://doi.org/10.1029/2006JD007125, 2006.

Ng, N. L., Herndon, S. C., Trimborn, A., Canagaratna, M. R., Croteau, P. L., Onasch, T. B., Sueper, D., Worsnop, D. R., Zhang, Q., Sun, Y. L., and Jayne, J. T.: An aerosol chemical speciation monitor (ACSM) for routine monitoring of the composition and mass concentrations of ambient aerosol, Aerosol Sci. Tech., 45, 780-794, https://doi.org/10.1080/02786826.2011.560211, 2011.

Ni, H., Huang, R.-J., Cao, J., Liu, W., Zhang, T., Wang, M., Meijer, H. A. J., and Dusek, U.: Source apportionment of carbonaceous aerosols in Xi'an, China: insights from a full year of measurements of radiocarbon and the stable isotope ${ }^{13} \mathrm{C}$, Atmos. Chem. Phys., 18, 16363-16383, https://doi.org/10.5194/acp-18-163632018, 2018.

Ni, H., Huang, R.-J., Cao, J., Dai, W., Zhou, J., Deng, H., AertsBijma, A., Meijer, H. A. J., and Dusek, U.: High contributions of fossil sources to more volatile organic aerosol, Atmos. Chem. Phys., 19, 10405-10422, https://doi.org/10.5194/acp-19-104052019, 2019.

Paatero, P. and Tapper, U.: Positive matrix factorization a nonnegative factor model with optimal utilization of error estimates of data values, Environmetrics, 5, 111-126, https://doi.org/10.1002/env.3170050203, 1994.

Palstra, S. W. L. and Meijer, H. A. J.: Biogenic carbon fraction of biogas and natural gas fuel mixtures determined with ${ }^{14} \mathrm{C}$, Radiocarbon, 56, 7-28, https://doi.org/10.2458/56.16514, 2014.

Paraskevopoulou, D., Liakakou, E., Gerasopoulos, E., Theodosi, C., and Mihalopoulos, N.: Long-term characterization of organic and elemental carbon in the $\mathrm{PM}_{2.5}$ fraction: the case of Athens, Greece, Atmos. Chem. Phys., 14, 13313-13325, https://doi.org/10.5194/acp-14-13313-2014, 2014.

Pavuluri, C. M., Kawamura, K., Uchida, M., Kondo, M., and $\mathrm{Fu}, \mathrm{P}$. Q.: Enhanced modern carbon and biogenic organic tracers in Northeast Asian aerosols during spring/summer, J. Geophys. Res.-Atmos., 118, 2362-2371, https://doi.org/10.1002/jgrd.50244, 2013.

Puxbaum, H., Caseiro, A., Sánchez-Ochoa, A., Kasper-Giebl, A., Claeys, M., Gelencsér, A., Legrand, M., Preunkert, S., and Pio, C.: Levoglucosan levels at background sites in Europe for assessing the impact of biomass combustion on the European aerosol background, J. Geophys. Res.-Atmos., 112, D23S05, https://doi.org/10.1029/2006JD008114, 2007. 
Reyes-Villegas, E., Bannan, T., Le Breton, M., Mehra, A., Priestley, M., Percival, C., Coe, H., and Allan, J. D.: Online chemical characterization of food-cooking organic aerosols: Implications for source apportionment, Environ. Sci. Technol., 52, 5308-5318, https://doi.org/10.1021/acs.est.7b06278, 2018.

Robinson, A. L., Donahue, N. M., Shrivastava, M. K., Weitkamp, E. A., Sage, A. M., Grieshop, A. P., Lane, T. E., Pierce, J. R., and Pandis, S. N.: Rethinking organic aerosols: Semivolatile emissions and photochemical aging, Science, 315, 1259-1262, https://doi.org/10.1126/science.1133061, 2007.

Rogge, W. F., Hildemann, L. M., Mazurek, M. A., Cass, G. R., and Simoneit, B. R. T.: Sources of fine organic aerosol. 4. Particulate abrasion products from leaf surfaces of urban plants, Environ. Sci. Technol., 27, 2700-2711, https://doi.org/10.1021/es00049a008, 1993.

Salma, I., Németh, Z., Weidinger, T., Maenhaut, W., Claeys, M., Molnár, M., Major, I., Ajtai, T., Utry, N., and Bozóki, Z.: Source apportionment of carbonaceous chemical species to fossil fuel combustion, biomass burning and biogenic emissions by a coupled radiocarbon-levoglucosan marker method, Atmos. Chem. Phys., 17, 13767-13781, https://doi.org/10.5194/acp-17-137672017, 2017.

Sciare, J., d'Argouges, O., Sarda-Esteve, R., Gaimoz, C., Dolgorouky, C., Bonnaire, N., Favez, O., Bonsang, B., and Gros, V.: Large contribution of water-insoluble secondary organic aerosols in the region of Paris (France) during wintertime, J. Geophys. Res.-Atmos., 116, D22203, https://doi.org/10.1029/2011jd015756, 2011.

Shi, Z., Vu, T., Kotthaus, S., Harrison, R. M., Grimmond, S., Yue, S., Zhu, T., Lee, J., Han, Y., Demuzere, M., Dunmore, R. E., Ren, L., Liu, D., Wang, Y., Wild, O., Allan, J., Acton, W. J., Barlow, J., Barratt, B., Beddows, D., Bloss, W. J., Calzolai, G., Carruthers, D., Carslaw, D. C., Chan, Q., Chatzidiakou, L., Chen, Y., Crilley, L., Coe, H., Dai, T., Doherty, R., Duan, F., Fu, P., Ge, B., Ge, M., Guan, D., Hamilton, J. F., He, K., Heal, M., Heard, D., Hewitt, C. N., Hollaway, M., Hu, M., Ji, D., Jiang, X., Jones, R., Kalberer, M., Kelly, F. J., Kramer, L., Langford, B., Lin, C., Lewis, A. C., Li, J., Li, W., Liu, H., Liu, J., Loh, M., Lu, K., Lucarelli, F., Mann, G., McFiggans, G., Miller, M. R., Mills, G., Monk, P., Nemitz, E., O'Connor, F., Ouyang, B., Palmer, P. I., Percival, C., Popoola, O., Reeves, C., Rickard, A. R., Shao, L., Shi, G., Spracklen, D., Stevenson, D., Sun, Y., Sun, Z., Tao, S., Tong, S., Wang, Q., Wang, W., Wang, X., Wang, X., Wang, Z., Wei, L., Whalley, L., Wu, X., Wu, Z., Xie, P., Yang, F., Zhang, Q., Zhang, Y., Zhang, Y., and Zheng, M.: Introduction to the special issue "In-depth study of air pollution sources and processes within Beijing and its surrounding region (APHH-Beijing)", Atmos. Chem. Phys., 19, 7519-7546, https://doi.org/10.5194/acp19-7519-2019, 2019.

Simoneit, B. R. T., Schauer, J. J., Nolte, C. G., Oros, D. R., Elias, V. O., Fraser, M. P., Rogge, W. F., and Cass, G. R.: Levoglucosan, a tracer for cellulose in biomass burning and atmospheric particles, Atmos. Environ. 33, 173-182, https://doi.org/10.1016/S13522310(98)00145-9, 1999.

Song, Y., Tang, X., Xie, S., Zhang, Y., Wei, Y., Zhang, M., Zeng, L., and Lu S.: Source apportionment of $\mathrm{PM}_{2.5}$ in Beijing in 2004, J. Hazard. Mater., 146, 124-130, https://doi.org/10.1016/j.jhazmat.2006.11.058, 2007.
Sullivan, A. P., Guo, H., Schroder, J. C., Campuzano-Jost, P., Jimenez, J. L., Campos, T., Shah, V., Jaegle, L., Lee, B. H., Lopez-Hilfiker, F. D., Thornton, J. A., Brown, S. S., and Weber, R. J.: Biomass burning markers and residential burning in the WINTER aircraft campaign, J. Geophys. Res.-Atmos., 124, 1846-1861, https://doi.org/10.1029/2017JD028153, 2019.

Sun, J., Shen, Z. X., Zhang, Y., Zhang, Q., Lei, Y. L., Huang, Y., Niu, X. Y., Xu, H. M., Cao, J. J., Ho, S. S. $\mathrm{H}$., and $\mathrm{Li}, \mathrm{X}$. X.: Characterization of $\mathrm{PM}_{2.5}$ source profiles from typical biomass burning of maize straw, wheat straw, wood branch, and their processed products (briquette and charcoal) in China, Atmos. Environ., 205, 36-45, https://doi.org/10.1016/j.atmosenv.2019.02.038, 2019a.

Sun, J., Shen, Z. X., Zhang, Y., Zhang, Q., Wang, F. R., Wang, T., Chang, X. J., Lei, Y. L., Xu, H. M., Cao, J. J., Zhang, N. N., Liu, S. X., and Li, X. X.: Effects of biomass briquetting and carbonization on $\mathrm{PM}_{2.5}$ emission from residential burning in Guanzhong Plain, China, Fuel, 244, 379-387, https://doi.org/10.1016/j.fuel.2019.02.031, 2019b.

Sun, Y., Jiang, Q., Xu, Y., Ma, Y., Zhang, Y., Liu, X., Li, W., Wang, F., Li, J., Wang, P., and Li, Z.: Aerosol characterization over the North China Plain: Haze life cycle and biomass burning impacts in summer, J. Geophys. Res.-Atmos., 121, 2508-2521, https://doi.org/10.1002/2015JD024261, 2016.

Sun, Y., He, Y., Kuang, Y., Xu, W., Song, S., Ma, N., Tao, J., Cheng, P., Wu, C., Su, H., Cheng, Y., Xie, C., Chen, C., Lei, L., Qiu, Y., Fu, P., Croteau, P., and Worsnop, D. R.: Chemical differences between $\mathrm{PM}_{1}$ and $\mathrm{PM}_{2.5}$ in highly polluted environment and implications in air pollution studies, Geophys. Res. Lett., 47, e2019GL086288, https://doi.org/10.1029/2019GL086288, 2020.

Szidat, S., Jenk, T. M., Gäggeler, H. W., and Synal, H.-A.: Source apportionment of aerosols by ${ }^{14} \mathrm{C}$ measurements in different carbonaceous particle fractions, Radiocarbon, 46, 475-484, https://doi.org/10.1017/S0033822200039783, 2004.

Szidat, S., Jenk, T. M., Synal, H.-A. Kalberer, M., Wacker, L., Hajdas, I., Kasper-Giebl, A., Baltensperger, U.: Contributions of fossil fuel, biomass-burning, and biogenic emissions to carbonaceous aerosols in Zurich as traced by ${ }^{14} \mathrm{C}$, J. Geophys. Res.Atmos., 111, D07206, https://doi.org/10.1029/2005JD006590, 2006.

Szidat, S., Ruff, M., Perron, N., Wacker, L., Synal, H.-A., Hallquist, M., Shannigrahi, A. S., Yttri, K. E., Dye, C., and Simpson, D.: Fossil and non-fossil sources of organic carbon (OC) and elemental carbon (EC) in Göteborg, Sweden, Atmos. Chem. Phys., 9, 1521-1535, https://doi.org/10.5194/acp-9-1521-2009, 2009.

Szidat, S., Salazar, G. A., Vogel, E., Battaglia, M., Wacker, L., Synal, H.-A., and Türler, A.: ${ }^{14} \mathrm{C}$ analysis and sample preparation at the new bern laboratory for the analysis of radiocarbon with AMS (LARA), Radiocarbon, 56, 561-566, https://doi.org/10.2458/56.17457, 2014.

Ulbrich, I. M., Canagaratna, M. R., Zhang, Q., Worsnop, D. R., and Jimenez, J. L.: Interpretation of organic components from Positive Matrix Factorization of aerosol mass spectrometric data, Atmos. Chem. Phys., 9, 2891-2918, https://doi.org/10.5194/acp-92891-2009, 2009.

Vlachou, A., Daellenbach, K. R., Bozzetti, C., Chazeau, B., Salazar, G. A., Szidat, S., Jaffrezo, J.-L., Hueglin, C., Baltensperger, U., Haddad, I. E., and Prévôt, A. S. H.: Advanced source apportionment of carbonaceous aerosols by coupling offline 
AMS and radiocarbon size-segregated measurements over a nearly 2-year period, Atmos. Chem. Phys., 18, 6187-6206, https://doi.org/10.5194/acp-18-6187-2018, 2018.

Wang, Q., Shao, M., Zhang, Y., Wei, Y., Hu, M., and Guo, S.: Source apportionment of fine organic aerosols in Beijing, Atmos. Chem. Phys., 9, 8573-8585, https://doi.org/10.5194/acp-9-8573-2009, 2009

Wu, X., Chen, C., Vu, T. V., Liu, D., Baldo, C., Shen, X., Zhang, Q., Cen, K., Zheng, M., He, K., Shi, Z., and Harrison, R. M.: Source apportionment of fine organic carbon (OC) using receptor modelling at a rural site of Beijing: Insight into seasonal and diurnal variation of source contributions, Environ. Pollut., 266, 115078, https://doi.org/10.1016/j.envpol.2020.115078, 2020.

Xu, J., Song, S., Harrison, R. M., Song, C., Wei, L., Zhang, Q., Sun, Y., Lei, L., Zhang, C., Yao, X., Chen, D., Li, W., Wu, M., Tian, H., Luo, L., Tong, S., Li, W., Wang, J., Shi, G., Huangfu, Y., Tian, Y., Ge, B., Su, S., Peng, C., Chen, Y., Yang, F., Mihajlidi-Zelić, A., Đorđević, D., Swift, S. J., Andrews, I., Hamilton, J. F., Sun, Y., Kramawijaya, A., Han, J., Saksakulkrai, S., Baldo, C., Hou, S., Zheng, F., Daellenbach, K. R., Yan, C., Liu, Y., Kulmala, M., Fu, P., and Shi, Z.: An interlaboratory comparison of aerosol inorganic ion measurements by ion chromatography: implications for aerosol pH estimate, Atmos. Meas. Tech., 13, 6325-6341, https://doi.org/10.5194/amt-13-6325-2020, 2020.

Xu, J., Liu, D., Wu, X., Vu, T. V., Zhang, Y., Fu, P., Sun, Y., Xu, W., Zheng, B., Harrison, R. M., and Shi, Z.: Source apportionment of fine organic carbon at an urban site of Beijing using a chemical mass balance model, Atmos. Chem. Phys., 21, 7321-7341, https://doi.org/10.5194/acp-21-7321-2021, 2021.

Xu, W., Sun, Y., Wang, Q., Zhao, J., Wang, J., Ge, X., Xie, C., Zhou, W., Du, W., Li, J., Fu, P., Wang, Z., Worsnop, D. R., Coe, H.: Changes in aerosol chemistry from 2014 to 2016 in winter in Beijing: insights from high-resolution aerosol mass spectrometry, J. Geophys. Res.-Atmos., 124, 1132-1147, https://doi.org/10.1029/2018JD029245, 2019.

Yan, C., Zheng, M., Sullivan, A. P., Shen, G., Chen, Y., Wang, S., Zhao, B., Cai, S., Desyaterik, Y., X. Li, Zhou, T., Ö. Gustafsson, and Collett Jr., J. L.: Residential coal combustion as a source of levoglucosan in China, Environ. Sci. Technol., 52, 1665-1674, https://doi.org/10.1021/acs.est.7b05858, 2018.

Yan, C. Q., Sullivan, A. P., Cheng, Y., Zheng, M., Zhang, Y. H., Zhu, T., and Collett, J. L.: Characterization of saccharides and associated usage in determining biogenic and biomass burning aerosols in atmospheric fine particulate matter in the North China Plain, Sci. Total Environ., 650, 2939-2950, https://doi.org/10.1016/j.scitotenv.2018.09.325, 2019.

Yan, X., Ohara, T., and Akimoto, H.: Bottom-up estimate of biomass burning in mainland China, Atmos. Environ., 40, 52625273, https://doi.org/10.1016/j.atmosenv.2006.04.040, 2006.

Yang, F., Kawamura, K., Chen, J., Ho, K., Lee, S., Gao, Y., Cui, L., Wang, T., and Fu, P.: Anthropogenic and biogenic organic compounds in summertime fine aerosols $\left(\mathrm{PM}_{2.5}\right)$ in Beijing, China, Atmos. Environ., 124, 166-175, https://doi.org/10.1016/j.atmosenv.2015.08.095, 2016.

Yin, J., Harrison, R. M., Chen, Q., Rutter, A., and Schauer, J. J.: Source apportionment of fine particles at urban background and rural sites in the UK atmosphere, Atmos. Environ., 44, 841-851, https://doi.org/10.1016/j.atmosenv.2009.11.026, 2010.
Yin, J., Cumberland, S. A., Harrison, R. M., Allan, J., Young, D. E., Williams, P. I., and Coe, H.: Receptor modelling of fine particles in southern England using CMB including comparison with AMS-PMF factors, Atmos. Chem. Phys., 15, 2139-2158, https://doi.org/10.5194/acp-15-2139-2015, 2015.

Yttri, K. E., Simpson, D., Stenström, K., Puxbaum, H., and Svendby, T.: Source apportionment of the carbonaceous aerosol in Norway - quantitative estimates based on ${ }^{14} \mathrm{C}$, thermal-optical and organic tracer analysis, Atmos. Chem. Phys., 11, 9375-9394, https://doi.org/10.5194/acp-11-9375-2011, 2011.

Zdráhal, Z., Oliveira, J., Vermeylen, R., Claeys, M., and Maenhaut W.: Improved method for quantifying levoglucosan and related monosaccharide anhydrides in atmospheric aerosols and application to samples from urban and tropical locations, Environ. Sci. Technol., 36, 747-753, https://doi.org/10.1021/es015619v, 2002.

Zhang, T., Claeys, M., Cachier, H., Dong, S., Wang, W., Maenhaut, W., and Liu, X.: Identification and estimation of the biomass burning contribution to Beijing aerosol using levoglucosan as a molecular marker, Atmos. Environ., 42, 7013-7021, https://doi.org/10.1016/j.atmosenv.2008.04.050, 2008.

Zhang, X., Hecobian, A., Zheng, M., Frank, N. H., and Weber, R. J.: Biomass burning impact on $\mathrm{PM}_{2.5}$ over the southeastern US during 2007: integrating chemically speciated FRM filter measurements, MODIS fire counts and PMF analysis, Atmos. Chem. Phys., 10, 6839-6853, https://doi.org/10.5194/acp10-6839-2010, 2010.

Zhang, X., Lu. Y., Wang. Q., and Qian X.: A highresolution inventory of air pollutant emissions from crop residue burning in China, Atmos. Environ., 213, 207-214, https://doi.org/10.1016/j.atmosenv.2019.06.009, 2019.

Zhang, Y., Ren, H., Sun, Y., Cao, F., Chang, Y., Liu, S., Lee, X., Agrios, K., Kawamura, K., Liu, D., Ren, L., Du, W., Wang, Z., Prévôt, A. S. H., Szidat, S., and Fu, P.: High contribution of nonfossil sources to submicrometer organic aerosols in Beijing, China, Environ. Sci. Technol., 51, 7842-7852, https://doi.org/10.1021/acs.est.7b01517, 2017.

Zhang, Y. L., Perron, N., Ciobanu, V. G., Zotter, P., Minguillón, M. C., Wacker, L., Prévôt, A. S. H., Baltensperger, U., and Szidat, S.: On the isolation of OC and EC and the optimal strategy of radiocarbon-based source apportionment of carbonaceous aerosols, Atmos. Chem. Phys., 12, 10841-10856, https://doi.org/10.5194/acp-12-10841-2012, 2012.

Zhang, Y.-L., Huang, R.-J., El Haddad, I., Ho, K.-F., Cao, J.-J., Han, Y., Zotter, P., Bozzetti, C., Daellenbach, K. R., Canonaco, F., Slowik, J. G., Salazar, G., Schwikowski, M., Schnelle-Kreis, J., Abbaszade, G., Zimmermann, R., Baltensperger, U., Prévôt, A. S. H., and Szidat, S.: Fossil vs. non-fossil sources of fine carbonaceous aerosols in four Chinese cities during the extreme winter haze episode of 2013, Atmos. Chem. Phys., 15, 1299-1312, https://doi.org/10.5194/acp-15-1299-2015, 2015.

Zhang, Y.-L., Kawamura, K., Agrios, K., Lee, M., Salazar, G., and Szidat, S.: Fossil and nonfossil sources of organic and elemental carbon aerosols in the outflow from Northeast China, Environ. Sci. Technol., 50, 6284-6292, https://doi.org/10.1021/acs.est.6b00351, 2016.

Zhang, Y.-L., El-Haddad, I., Huang, R.-J., Ho, K.-F., Cao, J.-J., Han, Y., Zotter, P., Bozzetti, C., Daellenbach, K. R., Slowik, J. G., Salazar, G., Prévôt, A. S. H., and Szidat, S.: Large contribution of fossil fuel derived secondary organic carbon to water soluble or- 
ganic aerosols in winter haze in China, Atmos. Chem. Phys., 18, 4005-4017, https://doi.org/10.5194/acp-18-4005-2018, 2018.

Zhang, Y. X., Schauer, J. J., Zhang, Y. H., Zeng, L. M., Wei, Y. J., Liu, Y., and Shao, M.: Characteristics of particulate carbon emissions from real-world Chinese coal combustion, Environ. Sci. Technol., 42, 5068-5073, https://doi.org/10.1021/es7022576, 2008.

Zhang, Y.-X., Shao, M., Zhang, Y.-H., Zeng, L.-M, He, L.-Y, Zhu, B., We, Y.-J., Zhu, X.-L.: Source profiles of particulate organic matters emitted from cereal straw burnings, J. Environ. Sci., 19, 167-175, https://doi.org/10.1016/S1001-0742(07)60027-8, 2007.

Zhao, X., Hu, Q., Wang, X., Ding, X., He, Q., Zhang, Z., Shen, R., Lü, S., Liu, T., Fu, X., and Chen, L.: Composition profiles of organic aerosols from Chinese residential cooking: case study in urban Guangzhou, south China, J. Atmos. Chem., 72, 1-18, https://doi.org/10.1007/s10874-015-9298-0, 2015.

Zhou, W., Wang, Q., Zhao, X., Xu, W., Chen, C., Du, W., Zhao, J., Canonaco, F., Prévôt, A. S. H., Fu, P., Wang, Z., Worsnop, D. R., and Sun, Y.: Characterization and source apportionment of organic aerosol at $260 \mathrm{~m}$ on a meteorological tower in Beijing, China, Atmos. Chem. Phys., 18, 3951-3968, https://doi.org/10.5194/acp-18-3951-2018, 2018.
Zhou, Y., Xing, X., Lang, J., Chen, D., Cheng, S., Wei, L., Wei, $\mathrm{X}$., and Liu, C.: A comprehensive biomass burning emission inventory with high spatial and temporal resolution in China, Atmos. Chem. Phys., 17, 2839-2864, https://doi.org/10.5194/acp17-2839-2017, 2017.

Zhu, C.-S., Cao, J.-J., Tsai, C.-J., Zhang, Z.-S., and Tao, J.: Biomass burning tracers in rural and urban ultrafine particles in Xi'an, China, Atmos. Pollut. Res., 8, 614-618, https://doi.org/10.1016/j.apr.2016.12.011, 2017.

Zotter, P., Ciobanu, V. G., Zhang, Y. L., El-Haddad, I., Macchia, M., Daellenbach, K. R., Salazar, G. A., Huang, R.-J., Wacker, L., Hueglin, C., Piazzalunga, A., Fermo, P., Schwikowski, M., Baltensperger, U., Szidat, S., and Prévôt, A. S. H.: Radiocarbon analysis of elemental and organic carbon in Switzerland during winter-smog episodes from 2008 to 2012 - Part 1: Source apportionment and spatial variability, Atmos. Chem. Phys., 14, 1355113570, https://doi.org/10.5194/acp-14-13551-2014, 2014. 